\title{
23. PALEOCLIMATIC APPLICATIONS OF DOWNHOLE LOGS: PLIOCENE-PLEISTOCENE RESULTS FROM HOLE 798B, SEA OF JAPAN ${ }^{1}$
}

\author{
Peter B. deMenocal, ${ }^{2}$ James F. Bristow, ${ }^{3}$ and Ruediger Stein ${ }^{4}$
}

\begin{abstract}
We address two key issues relevant to using downhole logs to obtain quantitative paleoclimate data: Tool resolution and the origin of log responses. The vertical resolution of a given logging device sets an upper limit on its temporal resolution, so we present theoretical estimates for the minimum sedimentation rates required to resolve bedding cycles at the primary orbital periodicities using the standard suite of Schlumberger logging tools. We also investigate the sedimentologic origin of the 5- to 6-m bedding cycles within the logging data collected at Hole 798B on the Oki Ridge. Contiguous 30-cm channel samples were taken from Cores 128-798B-13H, -14H, and -15H to mimic tool resolution, and these were analyzed for biogenic opal, carbonate, terrigenous percent, and bulk mineralogy by $\mathrm{X}$-ray diffraction.

The 5- to 6-m cycles apparent within the log data are equivalent to $\sim 40 \mathrm{k.y}$. based on the average sedimentation rate $(\sim 13 \mathrm{~cm} / \mathrm{k} . \mathrm{y}$.) of the 1.0- to 2.8-Ma sequence. The core data demonstrate that the log variations reflect periodic changes in opal and terrigenous sedimentation. Much of the log variance is concentrated at the $41-\mathrm{k} . \mathrm{y}$. obliquity band, and there is a close correspondence of the log data with the Pliocene-Pleistocene marine $\delta^{18} \mathrm{O}$ record. Quartz is highly correlated with terrigenous fraction variations, and the bulk mineralogical assemblage is similar to that of Chinese loess, a probable upwind source of eolian dust. The Chinese loess deposits indicate a linkage between glacial climate and Asian aridity, so the periodic increases in terrigenous concentration may reflect the downwind propagation of this signal. Alternatively, the logs could be reflecting variations in biogenic opal production resulting from glacial-interglacial changes in surface productivity.
\end{abstract}

\section{INTRODUCTION}

Although downhole logging instrumentation has been used for decades to service oil industry needs, the application of logging technology to basic scientific problems has yet to be fully exploited. Paleoclimate research is one of the more promising applications as climatically-modulated variations in biogenic (carbonate, opal, and organic carbon) and terrigenous (eolian) sediment components can affect the physical and chemical composition of the bulk deposited sediment. Analyses have traditionally been based on discrete samples from relatively short $(15-\mathrm{m})$ piston cores and, more recently, from longer drilled ODP sequences. Provided that downhole log variations can be demonstrated to be accurate and reliable proxy indicators of biogenic or terrigenous sediment variations, logs could offer a highly effective means for acquiring basic paleoclimatic data. Unlike core data, logging data are acquired continuously and rapidly, and they reflect in-situ properties. More importantly, because a full suite of electric, acoustic, and nuclear logging tools is employed, the logs offer several perspectives on changing sediment composition.

The principal limitation on integrating logging data into paleoclimate studies is the absence of a generally applicable method for transforming log data into reliable sediment component data. This problem is rooted in site-specific problems of establishing accurate core-log correlations as well as the more general limitations associated with the logging tools themselves. Each tool has its own intrinsic sensitivity and resolution characteristics. Thus, before logs can be considered an efficient means for augmenting discrete core analyses of sediment constituents, it is necessary to evaluate individual tool responses to known variations in sediment lithology.

This paper examines the sedimentologic origins of the logging data collected at Hole 798B in the Sea of Japan and discusses these results in terms of the potential uses of downhole measurements as a

' Pisciotto, K. A., Ingle, J. C., Jr., von Breymann, M. T., Barron, J., et al., 1992. Proc. ODP, Sci. Results, 127/128, Pt. 1: College Station, TX (Ocean Drilling Program).

${ }^{2}$ Lamont-Doherty Geological Observatory of Columbia University, Palisades, NY 10964.

${ }^{3}$ Department of Geology, University of Leicester, United Kingdom.

${ }^{4}$ Alfred-Wegener Institute for Polar and Marine Research, Bremerhaven, Federal Republic of Germany. parallel method for obtaining meaningful paleoclimate data from future ODP sites.

\section{SITE LOCATION}

Site $798\left(37^{\circ} 38^{\prime} \mathrm{N}, 134^{\circ} 80^{\prime} \mathrm{E}\right)$ is located in the southeastern Sea of Japan, about $160 \mathrm{~km}$ north of the western coast of Honshu (Fig. 1). The site is positioned over a small sediment-filled graben that lies on top of the Oki Ridge in $911.1 \mathrm{~m}$ water depth (Fig. 2). The primary drilling objective at this site was to obtain a Neogene sequence of pelagic-hemipelagic sediments deposited above the local carbonate compensation depth (CCD) currently near $1500 \mathrm{~m}$. This study focuses on the uppermost $\sim 320 \mathrm{~m}$ of Hole $798 \mathrm{~B}(\sim 2.9 \mathrm{Ma})$; core recovery and sediment quality below this depth were adversely affected by changes in lithology associated with carbonate diagenesis (first prominent occurrence of authigenic dolomite layers at $335 \mathrm{mbsf}$ ) and silica diagenesis (opal-A/opal-CT boundary at $445 \mathrm{mbsf}$ ).

The uppermost $320 \mathrm{~m}$ of Hole 798B are characterized by cycles of dark, organic-rich, laminated, diatomaceous clays interbedded with lighter-colored, bioturbated units richer in terrigenous clay and silt. The major sediment components are biogenic opal (5\%-25\%), carbonate $(0 \%-15 \%)$, terrigenous silts and clays $(40 \%-80 \%)$, and organic carbon $(2 \%-6 \%)$. Light-dark sedimentary cycles several decimeters long were commonly observed superimposed upon the longer, 5- to 6-m cycles. Discrete centimeter-scale volcanic ash beds are common throughout the Pleistocene portion of the record (Ma; $175 \mathrm{mbsf}$ ) but are notably less frequent in the older sediments. An excellent paleomagnetic stratigraphy was obtained (Hamano et al., this volume). Sedimentation rates above $320 \mathrm{mbsf}$ are high, ranging between 10 and $14 \mathrm{~cm} / \mathrm{k} . \mathrm{y}$.

\section{RESEARCH OBJECTIVES AND STRATEGY}

This paper presents initial results on the determination of quantitative paleoclimate data from downhole logs. The research strategy was designed to assess the responses of the logging tools to predetermined variations in sediment lithology and so to evaluate which tool responses have the best potential for resolving climatically-modulated variations in biogenic and terrigenous sedimentation. Hole 798B is ideally suited to the objectives of this study for several reasons. The 


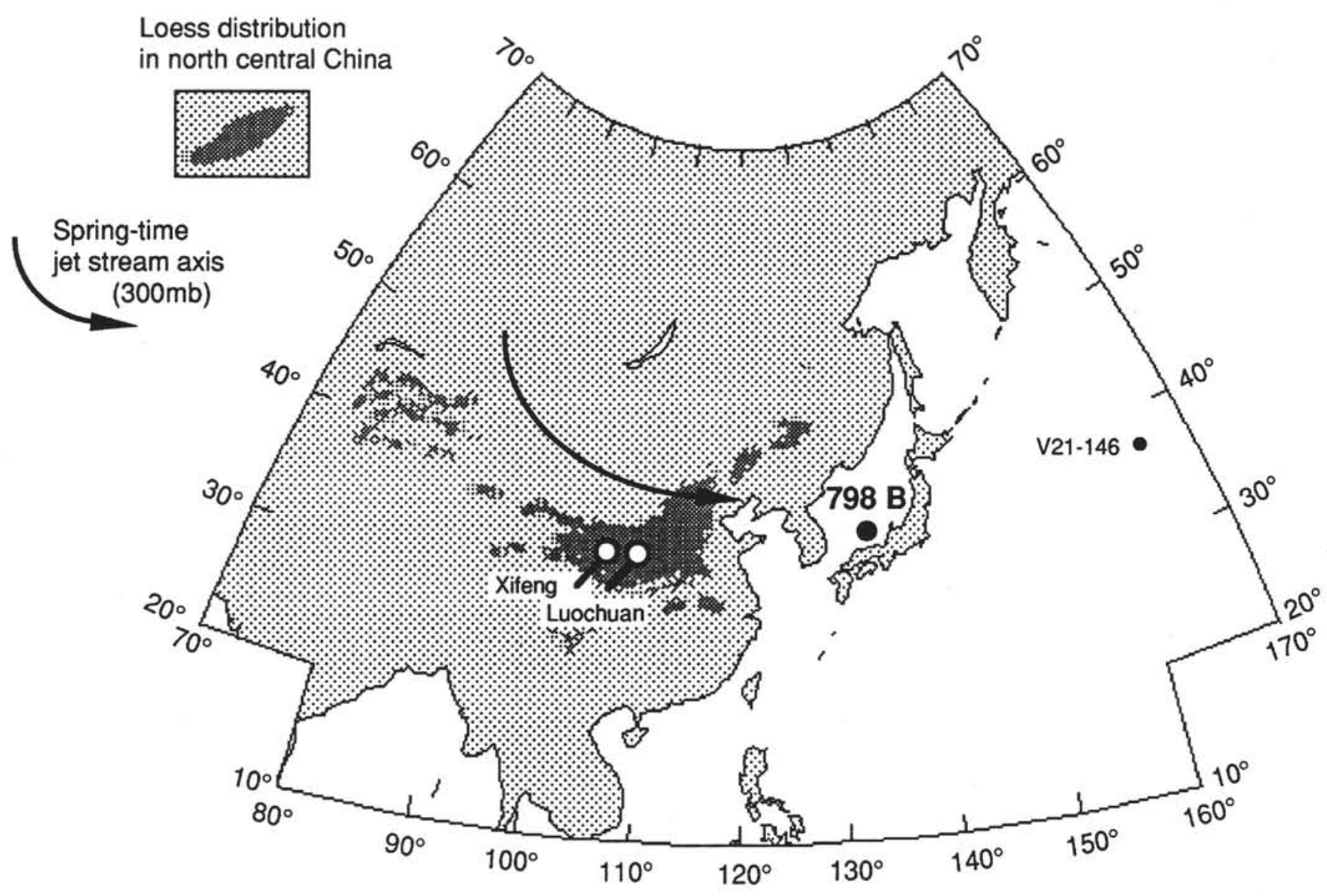

Figure 1. Location of Hole 798B relative to the Chinese loess plateau sediments and Core V21-146 from Hovan et al. (1989).

site is in a climatically sensitive location and several previous studies have discussed paleoceanographic and regional paleoclimatic changes associated with the last glacial maximum (LGM $~ 18$ k.y. ago: e.g., Ingle, 1973; Oba, 1983; Matoba, 1984; Huesser and Morley, 1990). Sedimentation rates are high $(10-14 \mathrm{~cm} / \mathrm{k} . \mathrm{y}$.) so time-dependent variations in lithology are relatively expanded in depth. Logging data are typically acquired at $15-\mathrm{cm}$ intervals which, given the sedimentation rates, corresponds to a temporal sample interval of $1-2 \mathrm{k} . \mathrm{y}$. We were able to use several thin ash layers which are dispersed throughout the Hole 798B sequence to establish depth correlations between cores and logs. Core recovery was generally excellent, although many of the XCB cores were disturbed by expanding interstitial gases during core recovery. Furthermore, sea-state conditions were favorable and there was enough time to run the entire suite of Schlumberger logs, including multiple runs for several tool strings.

\section{OCEANOGRAPHIC AND CLIMATIC SETTING}

The oceanographic setting of the Sea of Japan is unique because the inflow of adjacent Pacific intermediate waters is restricted by several shallow straits and sills $(\sim 100 \mathrm{~m})$ which rim the basin. Hydrographic soundings demonstrate that temperature, salinity, and dissolved oxygen in the Sea of Japan are homogeneous from $\sim 200 \mathrm{~m}$ to depths exceeding $3600 \mathrm{~m}$. Deep convection in the Sea of Japan is accomplished by winter freezing and sinking of surface waters in the northern reaches of the basin (Matoba, 1984). Hence, the modern Sea of Japan is thoroughly ventilated by cold $\left(0.2^{\circ} \mathrm{C}\right)$, moderately fresh $(34.1 \% \%)$, and highly oxygenated $\left(\left[\mathrm{O}_{2}\right]=5.3 \mathrm{ml} / \mathrm{L}\right)$ water. The modern CCD is $\sim 1500 \mathrm{~m}$ (Ujiie and Ichikura, 1973). Despite high surface productivity, the highly oxic conditions result in the deposition of low organic content, red-brown, diatomaceous clays.

Large-scale dust storms occur during springtime in northern China and Mongolia due to the seasonal passage of intense winds over drying soils. Dust is mixed upward along turbulent frontal zones into the upper-level westerlies, which carry dust eastward over the Sea of Japan and into the Pacific basin (Fig. 1; Liu et al., 1981; Uematsu et al., 1983). Asian dust falls are common during springtime in Japan, where they are referred to as kosa (literally "yellow sand") (Pye, 1987, p. 114). Dust plumes take $\sim 10$ days to reach the Hawaiian islands (Braaten and Cahill, 1986). The terrigenous mineralogy of surface sediments from the northwest Pacific is virtually identical to the mineralogy of Asian dust source areas (Blanc et al., 1985; Leinen, 1989).

Piston core data from the Sea of Japan demonstrate that oceanographic conditions were markedly different during the last glacial maximum. Glacial levels are often marked by organic-rich, commonly laminated olive sediments barren of benthic foraminifers and relatively low in biogenic opal (Miyake et al., 1968; Kobayashi and Nomura, 1972; Ingle, 1975; Oba, 1983; Matoba, 1984). Because sea levels were lower during glacial intervals (e.g., $-120 \mathrm{~m}$ at LGM; Fairbanks, 1989), the glacial Sea of Japan has been variously depicted as an isolated inland sea with little or no communication with adjacent Pacific waters. Loss of open water exchange with the Pacific and expanded sea ice cover in the northern Sea of Japan are considered primary factors responsible for the onset of anoxic and reducing conditions in cores as shallow as $\sim 900 \mathrm{~m}$ (Miyake et al., 1968; Ujiie and Ichikura, 1973).

Pollen and radiolarian assemblage data have been used to monitor glacial-interglacial changes in regional terrestrial climate and surface 


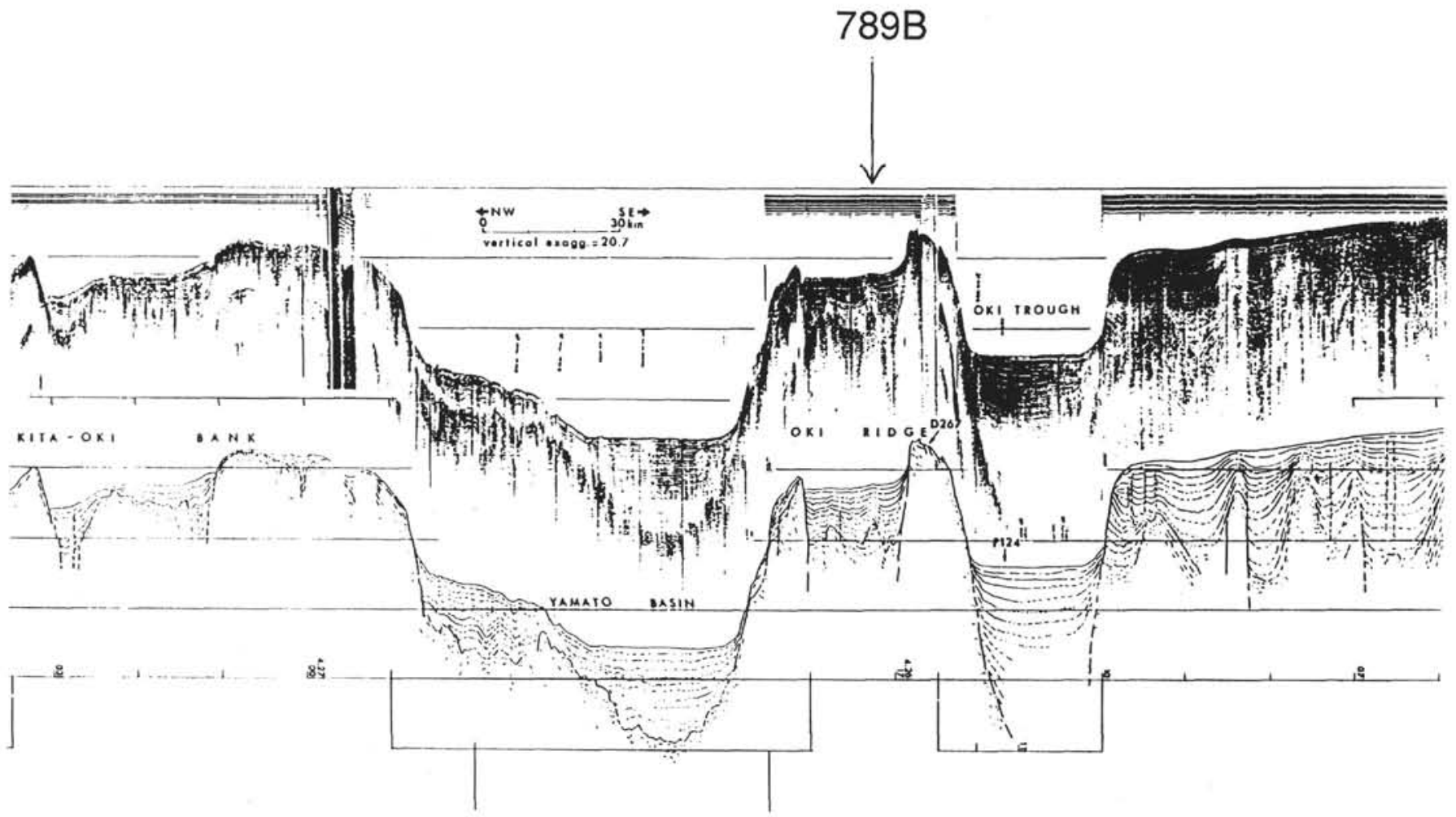

Figure 2. Northwest-southeast single-channel seismic reflection profile showing the location of Hole 798B on the Oki Ridge (data from Tamaki et al., 1988).

ocean conditions. These data indicate that a much colder and drier climate prevailed in the Sea of Japan region during the LGM (Morley et al., 1986; Heusser and Morley, 1990). In a detailed study of the Pleistocene-Holocene transition in several cores from the central Sea of Japan, Heusser and Morley (1990) demonstrated that glacial levels were dominated by boreal (cold) pine and spruce pollen whereas Holocene sediments are dominated by temperate (warmer) oak pollen. Pollen-based estimates of the temperature depression in the Sea of Japan are similar to those suggested for northern Europe during the LGM (Tsukada, 1983). While the radiolarian data indicate a glacial cooling of the surface ocean (Morley et al., 1986), they do not support the total isolation of the Sea of Japan as proposed by Ujiie and Ichikura (1973).

Accumulations of wind-blown loess in central and eastern China (Fig. 1) have been shown to be highly correlated to the marine $\delta^{18} \mathrm{O}$ continental ice volume record, providing strong evidence linking development of aridity on the Asian continent to glacial maxima (e.g., Kukla et al., 1988). A 400-k.y. record of eolian dust accumulation in the adjacent western Pacific closely parallels the Chinese loess record, suggesting that the continental aridity signal is preserved downwind in marine sediments (Hovan et al., 1989). In contrast, mineralogical analyses of samples from a transect of cores in the northwest Pacific did not detect any significant glacial-interglacial change in eolian sediment accumulation rates (Leinen, 1989). The Sea of Japan occupies an intermediate position between dust sources in Asia and dust accumulation records in the western Pacific.

\section{METHODS}

\section{Logging Operations}

After the completion of coring operations at Hole 798B, the drill string casing was raised to $85 \mathrm{mbsf}$, the hole was flushed of debris, and four combination Schlumberger tool strings were run into Hole 798B. A combination tool string consists of several separate logging devices that are joined together; a schematic diagram of the four tool strings is shown in Figure 3. A summary of the logging operations at this hole and descriptions of the individual tools deployed at this site are presented in the "Explanatory Notes" and "Site 798'' chapters of the Proceedings of the Ocean Drilling Program, Initial Reports (Ingle, Suyehiro, von Breymann, et al., 1990).

An hydraulic wireline heave compensator was employed during each of the runs to minimize the effects of ship heave on the tool transit in the borehole. The natural gamma-ray tool (NGT) is used on each of the combination tool strings to provide a means for correlating the different logging runs to a common log depth scale. The NGT uses a scintillation detector to measure the natural radioactive decay of $\mathrm{K}$, $\mathrm{Th}$, and $\mathrm{U}$ within the formation. The seismic stratigraphic NGT run was selected as the reference gamma-ray log, since logging speeds were fastest and sea-state conditions were calmest for this run; NGT data from the other tool strings were correlated to the reference NGT, and their associated log data were depth-shifted accordingly.

The long-spaced sonic (LSS) tool employs two acoustic transmitters and receivers to measure sonic slowness $(\Delta \mathrm{t}), P$-wave velocity, and full sonic waveforms. The phasor dual induction tool (DIT) provides deep and medium measurements of electrical resistivity. The spherically focused $\log$ (SFL) produces the highest resolution resistivity logs of the induction tools. The lithodensity tool (LDT) emits $0.66-\mathrm{MeV}$ gamma rays from a pad-mounted ${ }^{137} \mathrm{Ce}$ source to measure bulk (electron) density by Compton scattering. This device also measures photoelectric absorption from electron capture triggered by neutrons reduced to thermal energies; the photoelectric effect $\left(\mathrm{P}_{e}\right)$ is independent of density and is useful as a lithology indicator. The compensated neutron tool (CNT-G) emits 5-MeV neutrons from an eccentralized Am-Be source and uses thermal/epithermal detectors to estimate hydrogen content and formation porosity. The formation microscanner (FMS), a relatively new tool, uses 16 microelectrode "buttons" on each of four orthogonal pads to produce very highresolution $(5 \mathrm{~mm})$ resistivity images of the borehole wall. The FMS data are oriented spatially by 3 -axis magnetometer accelerometer data from the general purpose inclination tool (GPIT). The induced gamma-ray spectroscopy tool (GST) estimates the mass abundances of $\mathrm{Ca}, \mathrm{Si}, \mathrm{Fe}, \mathrm{Cl}$, 

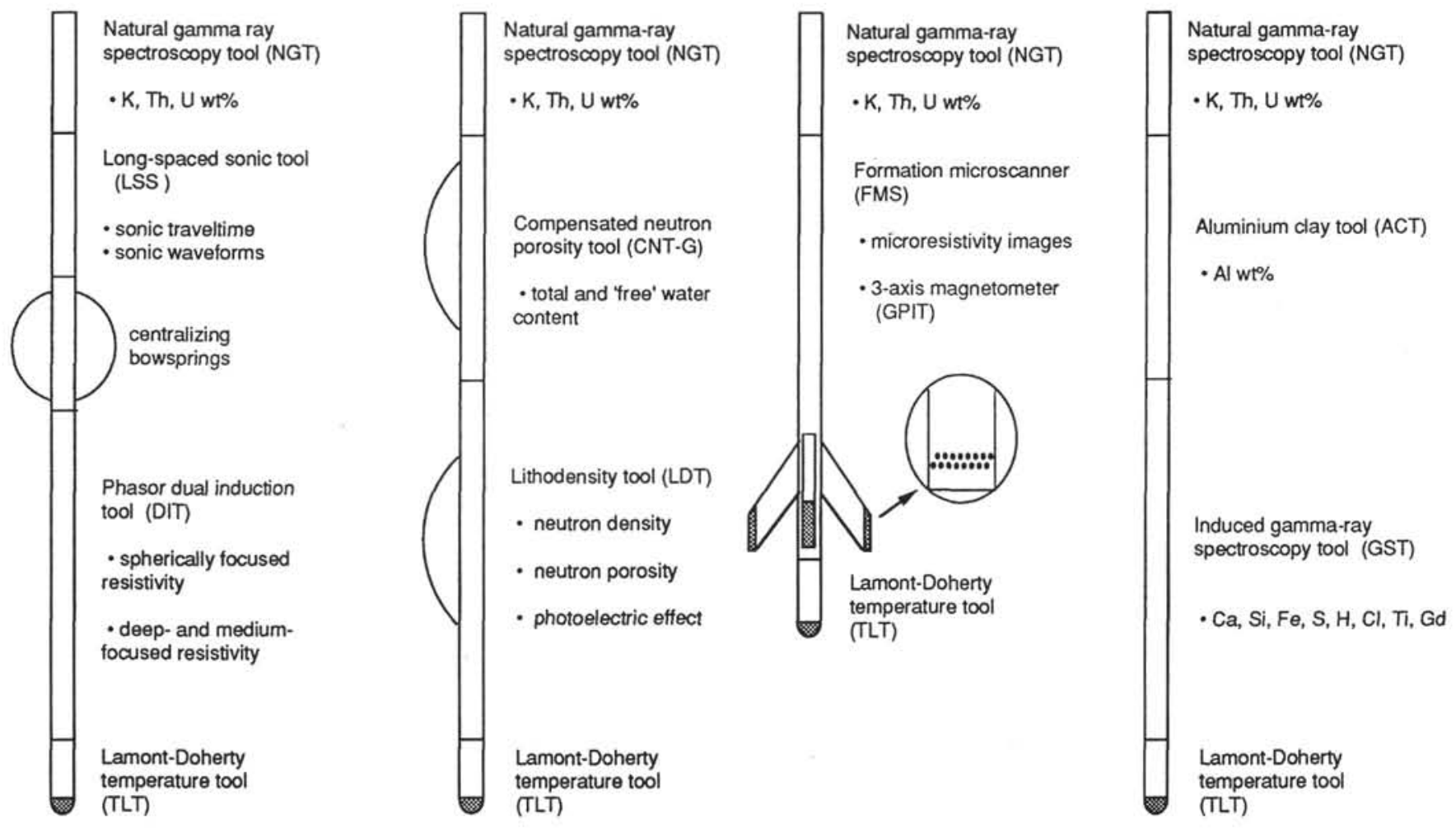

Figure 3. Schematic diagram of the four Schlumberger logging combination tool strings deployed on Leg 128. Note that the tools are not drawn to scale.

$\mathrm{H}$, and $\mathrm{S}$ based on capture gamma-ray spectrometry induced by 14-MeV neutrons emitted by a pulsed "minitron" tritium source. The aluminum clay tool (ACT) estimates the mass abundance of Al based on capture gamma-ray fluxes resulting from irradiation by a $2-\mathrm{MeV}$ Cf neutron source.

\section{Vertical Thickness Resolution}

Each logging device has a characteristic intrinsic vertical resolution, or vertical aperture. The vertical aperture of a given tool is defined as the thinnest interval for which a true, or representative, reading can be obtained. Although most tools can detect beds that are thinner than their vertical apertures (a function of tool sensitivity), such data are not accurate representations of the true lithologic properties. Vertical aperture has particular relevance to log-based paleoclimatic interpretations because the ability to resolve lithological variations with depth is directly equivalent to temporal resolution. The vertical aperture of a given tool is set by the physics of the measurement, the sensor spacing, the data sampling interval, and, in some cases, the amount of data averaging applied at the well site (Allen et al., 1988). Although log data are typically sampled at $15-\mathrm{cm}$ intervals, vertical apertures range from $38 \mathrm{~cm}$ (LDT; bulk density) to $2 \mathrm{~m}$ (ILD, deep resistivity): A summary of the vertical apertures for the tools deployed on Leg 128 is shown in Figure 4 . The very high resolution of the FMS tool $(5 \mathrm{~mm})$ is unique and makes this a particularly promising tool for paleoclimate applications.

A guide to the temporal resolutions that can be expected from the ODP suite of logging tools is shown in Figure 5. The resolution in time that can be expected from any given tool is dependent upon the vertical aperture of that device and the sedimentation rates of the logged interval. For example, the NGT gamma-ray tool $(46-\mathrm{cm}$ vertical aperture) can only fully resolve a bed thickness equivalent to $\sim 9$ k.y., assuming a formation sedimentation rate of $5 \mathrm{~cm} / \mathrm{k} . \mathrm{y}$. The equivalent time resolution curve for each tool was calculated as: time resolution $(\mathrm{k} . \mathrm{y})=$. vertical aperture $(\mathrm{cm}) /$ sedimentation rate $(\mathrm{cm} / \mathrm{k} . \mathrm{y}$.$) ,$ for sedimentation rates ranging from 0.2 to $20 \mathrm{~cm} / \mathrm{k}$.y.

\section{Periodicity Resolution}

Studies of late Neogene climate change have typically focused on climate variability at the primary earth orbital periodicities of 23-19 k.y., 41 k.y., and 100 k.y. (e.g., Hays et al., 1976; Imbrie et al., 1984). The majority of Schlumberger logging tools have vertical apertures ranging from $38-76 \mathrm{~cm}$, so sedimentation rates between $2-4 \mathrm{~cm} / \mathrm{k}$.y. are necessary just for these tools to "see" a depth interval equivalent to 20 k.y. in time (Fig. 5). This is not the same as resolving a 20 k.y. periodicity; a one-wavelength, moving average of a sinusoid results in a featureless straight line (the arithmetic analog of vertical aperture). Hence, much finer time resolution is needed to adequately resolve orbital-scale sedimentary cycles.

To simulate the effect of vertical aperture on sediment cycle resolution, we constructed a simple numerical model that calculates a moving average of a sinusoid using a variable-length averaging window. The program passes a centered box-averaging window over a sinusoidal record and then calculates the amount of amplitude attenuation (relative to the original signal) due to the averaging process. The window lengths range from one window per wavelength (100\% attenuation) to seven windows per wavelength (3\% attenuation). The results shown in Figure 6 demonstrate that amplitude attenuation reduces to $1 / \mathrm{e}(\sim 37 \%)$ when an averaging window length equal to one-half the signal wavelength is used (i.e., two averaging windows per wavelength). Attenuation is reduced to $10 \%$ when the averaging window length is one-quarter of the wavelength (i.e., four averaging windows per wavelength). 


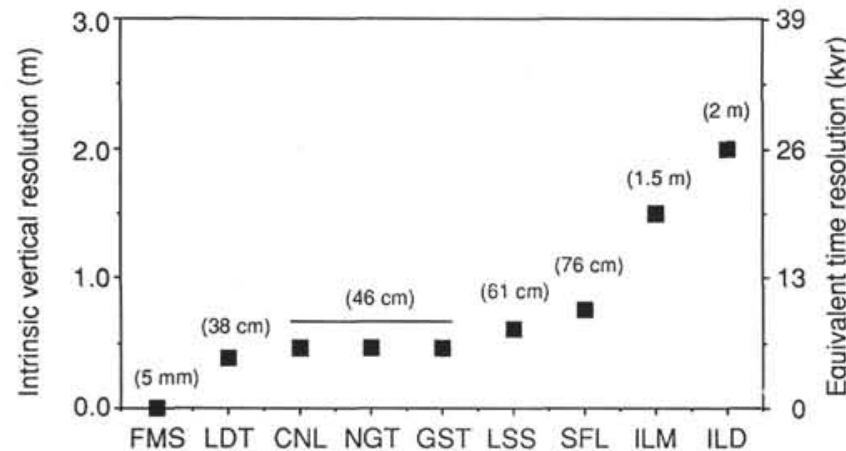

FMS formation microscanner
LDT lithodensitiy tool
CNL compensated neutron log
NGT natural gamma-ray spectrometry tool
GST gamma-ray spectroscopy tool
LSS long-spaced sonic tool
SFL spherically focused log
ILM phasor induction (medium)
ILD phasor induction (deep)

Figure 4. Plot of the intrinsic vertical resolutions of the Schlumberger logging tools deployed on Leg 128 (data from Allan et al., 1988). The vertical resolution, or aperture, is the minimum depth interval for which a representative log measurement can be obtained. Note that most tools have vertical apertures within a range of $38 \mathrm{~cm}$ to $76 \mathrm{~cm}$. The "Equivalent time resolution" scale to the right was calculated assuming the mean sedimentation rate at Site $798(\sim 13 \mathrm{~cm} / \mathrm{k} . \mathrm{y})$.

These results mean that sedimentation rates indicated by shaded bars in Figure 5 must be higher by a factor of at least two, and preferably four, to resolve bedding cycles that occur at the 100-k.y., 41-k.y., and 23-19 k.y. orbital periodicities. That is, sedimentation rates in excess of $4-8 \mathrm{~cm} / \mathrm{k} . \mathrm{y}$. are needed to adequately resolve sedimentary cycles at the 23-19 k.y precessional band using the standard suite of Schlumberger logging tools with vertical aperture ranging between $38 \mathrm{~cm}$ and $76 \mathrm{~cm}$. Similarly, sedimentation rates in excess of $2-4 \mathrm{~cm} / \mathrm{k} . \mathrm{y}$. and $0.8-1.6 \mathrm{~cm} / \mathrm{k} . \mathrm{y}$. are needed to resolve the 41-k.y. and 100-k.y. periodicities associated with orbital tilt and eccentricity (Fig. 6). These results are listed in Table 1.

\section{Core Sampling and Analyses}

We have employed a sampling strategy designed to mimic the vertical aperture properties of the logs. Three intervals between 100 $320 \mathrm{mbsf}$ in Hole 798B were selected for subsampling based on core quality, recovery, and the presence of ash layers for core-log correlations. A 1-2 cm ash layer was identified in Core 128-798B-15H-7 at $55 \mathrm{~cm}$, so $30-\mathrm{cm}$ channel samples were extracted from the centers of Cores $13 \mathrm{H}, 14 \mathrm{H}$, and $15 \mathrm{H}$. Samples were taken contiguously over the entire length of the cores, including the core catcher material.

The sampling method had to be changed for Cores 128-798B-19X$20 \mathrm{X}$ and $128-798 \mathrm{~B}-28 \mathrm{X}-33 \mathrm{X}$ due to ODP core curation restrictions. Instead of individual $30-\mathrm{cm}$ channel samples, three discrete $5 \mathrm{~cm}^{3}$ samples were taken at $10-\mathrm{cm}$ intervals and bagged as one composite sample. A $1-2 \mathrm{~cm}$ ash layer was identified in Core 128-798B-19X-3 at $82 \mathrm{~cm}$ and samples were taken from Cores 128-798B-19X and -20X. The approximate age of this ash $(\sim 1.54 \mathrm{Ma}$, estimated by linear interpolation between paleomagnetic datums) is within the $1.6 \pm 0.2 \mathrm{Ma}$ fission-track age for tuff

\section{Equivalent Time Resolution of Logging Tool Apertures}

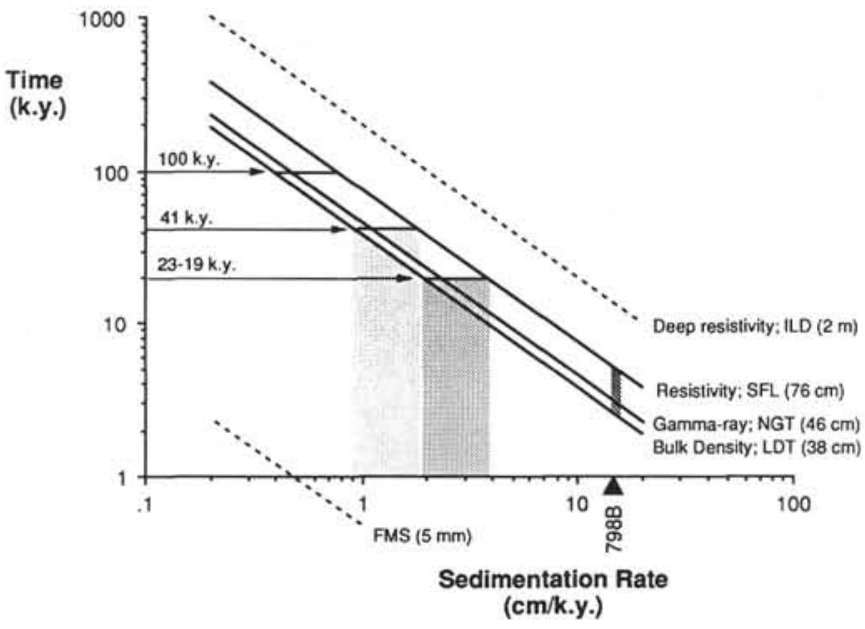

Figure 5. Plot of the temporal resolution of several logging tools as a function of sedimentation rate. Temporal resolution was calculated as vertical aperture/sedimentation rate. Minimum sedimentation rates required to resolve 100 k.y., 41 k.y., and 23-19 k.y. in time are shown as shaded columns. Note that these sedimentation rates are only sufficient to resolve a time interval $(\Delta t)$ equivalent to 100 k.y., 41 k.y., and 20 k.y.

\section{Amplitude}

attenuation
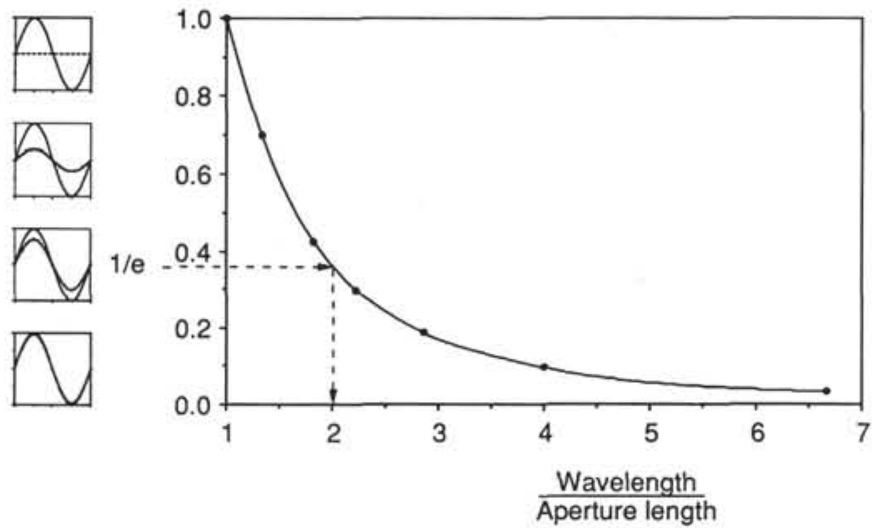

$$
\begin{array}{ll}
\text { - } 100 \text { k.y. } & \cdot 0.8-1.6 \mathrm{~cm} / \mathrm{k} . y . \\
\text { - } 41 \text { k.y. } & \cdot 2-4 \mathrm{~cm} / \mathrm{k} . \mathrm{y} . \\
\cdot 23-19 \text { k.y. } & \cdot 4-8 \mathrm{~cm} / \mathrm{k} . y .
\end{array}
$$$$
\text { Periodicity resolution Minimum required sedimentation rates }
$$

Figure 6. Calculated attenuation of a unit-wavelength sinusoid using a moving, centered box average window ranging in length from one window per wavelength (100\% attenuation) to seven windows per wavelength ( $3 \%$ attenuation). This exercise was conducted to simulate the effect of vertical aperture on the resolution of orbital bedding cycles. Plots of the full and attenuated amplitude signals are shown at left. These results suggest that a minimum of two aperture lengths per signal wavelength are required to obtain an e-folding signal resolution (i.e., $37 \%$ signal attenuation). These data were combined with the results in Figure 4 to estimate the minimum sedimentation rates necessary to resolve bedding cycles at the primary orbital periodicities using the standard suite of Schlumberger logging tools with apertures ranging from 38 to $76 \mathrm{~cm}$ (see Table 1). 
Table 1. Minimum sedimentation rates required to resolve orbital-scale bedding cycles within logs.

\begin{tabular}{lc} 
Periodicity resolution rates & Minimum required sedimentation \\
\hline 100 k.y. & $0.8-1.6 \mathrm{~cm} / \mathrm{k} . \mathrm{y}$. \\
41 k.y. & $1-2 \mathrm{~cm} / \mathrm{k} . \mathrm{y}$. \\
$23-19$ k.y. & $4-8 \mathrm{~cm} / \mathrm{k} . \mathrm{y}$. \\
\hline
\end{tabular}

layers collected from the Boso Peninsula, central Honshu (Kasuya, 1990). A 5-cm ash layer was identified in Core 128-798B-30X-4 at $40-45 \mathrm{~cm}$ and samples were taken from Cores 128-798B-28X to -33X. Data from these cores are not yet complete, so this paper will focus primarily on those data collected from Cores $128-798 \mathrm{~B}-13 \mathrm{H}$ to $-15 \mathrm{H}$. The estimated age range of the interval represented by Cores $128-798 \mathrm{~B}-13 \mathrm{H}-$ to $-15 \mathrm{H}$ is $\sim 1.1-1.3 \mathrm{Ma}$.

Each freeze-dried sample was gently disaggregated, and from each a small quantity was removed, ground, and placed in a separate vial. A total of 109 samples from Cores $128-798 \mathrm{~B}-13 \mathrm{H}$ to $-15 \mathrm{H}$ were analyzed for calcium carbonate, biogenic opal, and total carbon, as well as for quantitative X-ray diffraction bulk mineralogy and X-ray fluorescence major elemental abundances. Calcium carbonate was determined using a Coulometrics carbon dioxide coulometer equipped with a System 140 calcium carbonate analyzer. Calibration was achieved using reagent-grade $\mathrm{CaCO}_{3}$ and working standards; onesigma precision for $20-30 \mathrm{mg}$ replicate samples was $\pm 0.29 \mathrm{wt} \%$. Biogenic opal was determined using an alkaline $\left(\mathrm{NaCO}_{3}\right)$ extraction and spectrophotometric technique developed by Mortlock and Froelich (1989). Silica calibration was achieved using a series of analytical silica standards and opal percentages are reported as 2.4 times the [Si] concentration to account for the average water content of diatomaceous silica; one-sigma precision for $75 \mathrm{mg}$ replicate samples was $0.15 \mathrm{wt} \%$. Analyses of organic carbon were performed on a Carlo Erba Model NA1500 C/N/S analyzer using methods described by Verardo et al. (1990). These analyses are not yet completed but the organic carbon values obtained thus far range between $1 \%$ and $5 \mathrm{wt} \%$ and are generally high within the opal-rich zones. Quantitative X-ray mineralogy was conducted on powdered samples; $15 \mathrm{wt} \%$ corundum was added as an internal standard. Quartz, feldspar, muscovite, chlorite, and calcite were identified as the dominant diffracting minerals; the percentage data have not been normalized to $100 \%$. X-ray fluorescence elemental assays were conducted on all samples, and these data are described in more detail in Bristow and deMenocal (this volume).

\section{Results}

The gamma-ray, neutron bulk density, and resistivity $\operatorname{logs}$ (spherically-focused and medium induction) from 100-320 mbsf in Hole 798B are shown in Figure 7. Logging data above this interval were variously affected by data communication errors when the tool strings were stopped to re-enter casing set at $85 \mathrm{mbsf}$. Some residual effects are apparent in the anomalously low bulk density log data above $\sim 110$ mbsf. The Hole 798B paleomagnetic stratigraphy is shown adjacent to the log data, as are the core positions of the sampled intervals in Cores $128-798 \mathrm{~B}-13 \mathrm{H}$ to $-15 \mathrm{H}, 19 \mathrm{X}-20 \mathrm{X}$, and $28 \mathrm{X}-33 \mathrm{X}$. The magnetic polarity data indicate that the interval shown represents approximately $1.0 \mathrm{Ma}$ to $2.9 \mathrm{Ma}$.

\section{General Log Characteristics}

Several key features are immediately apparent in the logs. All of the logs covary and exhibit a well-defined 5- to 6-m cyclicity. The coincident gamma-ray, density, and resistivity peaks can be interpreted to reflect increases in terrigenous content relative to biogenic opal. Terrigenous clays have high $\mathrm{K}$ and $\mathrm{Th}$ contents and have relatively higher density and lower porosities than higher opal content sediments. Sediments rich in diatomaceous opal commonly have high porosities because of the intrinsically high porosity of the diatom tests themselves. Porosity is roughly proportional to the inverse square-root of resistivity (Archie, 1942), so the unusual trend of decreasing resistivity with depth apparent in Figure 7 may reflect increased opal contents deeper in the sequence. The core data support this conclusion: the average opal contents of the Cores 128-798B-13H to $-15 \mathrm{H}, 19 \mathrm{X}-20 \mathrm{X}$, and $28 \mathrm{X}$ $33 \mathrm{X}$ intervals are $10.1 \%, 14.3 \%$, and $22.0 \%$, respectively.

Ash layers in Hole 798B Cores 15H-7 $(55 \mathrm{~cm}), 19 \mathrm{X}-3(82 \mathrm{~cm})$, and $30 \mathrm{X}-4(40-45 \mathrm{~cm})$ were used to equate coring and logging depths. The glassy, impermeable nature of the ash layers makes them very highly resistive, and they can be recognized in the FMS microresistivity images as thin, well-defined, bright (light shading $=$ resistive) beds . The ash layer in Core $19 \mathrm{X}-3(82 \mathrm{~cm})$ was particularly well-defined, so the core photograph and FMS image data for this ash are shown in Figure 8 as an example. The ODP depths have been corrected for core expansion (ODP depths were adjusted so that recovered core equals $100 \%$ of the cored interval for all cores with reported recoveries exceeding $100 \%)$; the ash layer in Core $15 \mathrm{H}-7(55 \mathrm{~cm})$ corresponds to 140.70 mbsf drilling depth. The same ash layer was identified from FMS images at 140.40 mbsf logging depth. The excellent agreement between the drilling and logging depths $(0.30 \mathrm{~m}$ offset) is largely fortuitous; drilling and logging depth offsets were larger for the ashes in Cores 19X and 30X (drilling depths are deeper by +0.70 and +1.50 $\mathrm{m}$, respectively). A summary of the drilling and logging depth offsets is shown in Table 2. These linear offsets were applied to the core depths to align them with the logging depths. These offsets partially reflect real differences between logging and coring depths, but disturbance of the core and true section depths due to gas expansion is a probable contributor to the magnitude of the offset, particularly in the deepest $\mathrm{XCB}$ cores.

\section{Sediment Composition Data from Hole 798B Cores 128-798B-13H, -14H, -15H}

The gamma-ray, bulk density, and resistivity log data from 100-150 mbsf are shown adjacent to the depth-shifted opal, $\mathrm{CaCO}_{3}$, and terrigenous $\left(100-\left(\right.\right.$ opal $\left.\left.+\mathrm{CaCO}_{3}\right)\right)$ percent data from Cores $13 \mathrm{H}-15 \mathrm{H}$ in Figure 9. The position of the ash layer in Core $15 \mathrm{H}-7$ $(55 \mathrm{~cm})$ is indicated by a dashed line. The broad 5- to 6-m cycles in the log data are apparently reflecting the variations in sediment physical properties due to opal content variations. Increased opal content results in lower gamma-ray, bulk density, and resistivity log values. Low opal content is largely balanced by increases in terrigenous sediment, and this is recorded by the gamma-ray log. The $\mathrm{CaCO}_{3}$ variations are of approximately the same amplitude as the opal variations, yet these are not clearly apparent within the log data. Variations in opal content dominate the sediment physical properties recorded by the logging data. There is a very close correspondence between the highest resolution induction resistivity tool (the spherically focused $\log$; SFL) and the opal data. The 5- to 6-m cyclicity is apparent in both records, as well as a close correspondence of the shorter interval (1-2 $\mathrm{m})$ variations.

We used the close correspondence between the SFL and opal percent data as a means for refining the core-log correlations. The ash layer correlation is adequate to align the two records, but a more detailed correlation is required to account for minor depth offsets that occur at core breaks and, to a lesser extent, within core intervals. We used the CORPAC inverse correlation program (Martinson et al., 1982) to perform fine-scale alignment of the opal data (and their corresponding core depths) to the SFL log. The correlation between the opal and SFL data increased from 0.74 to 0.88 after this process. The maximum amplitude of the core depth adjustment from its original depth averaged $\pm 0.50 \mathrm{~m}$ and never exceeded $0.70 \mathrm{~m}$. The SFL $\log$ and the adjusted opal record are shown in Figure 10. The core depths are now "equivalent log depths"; all offsets between the cores 


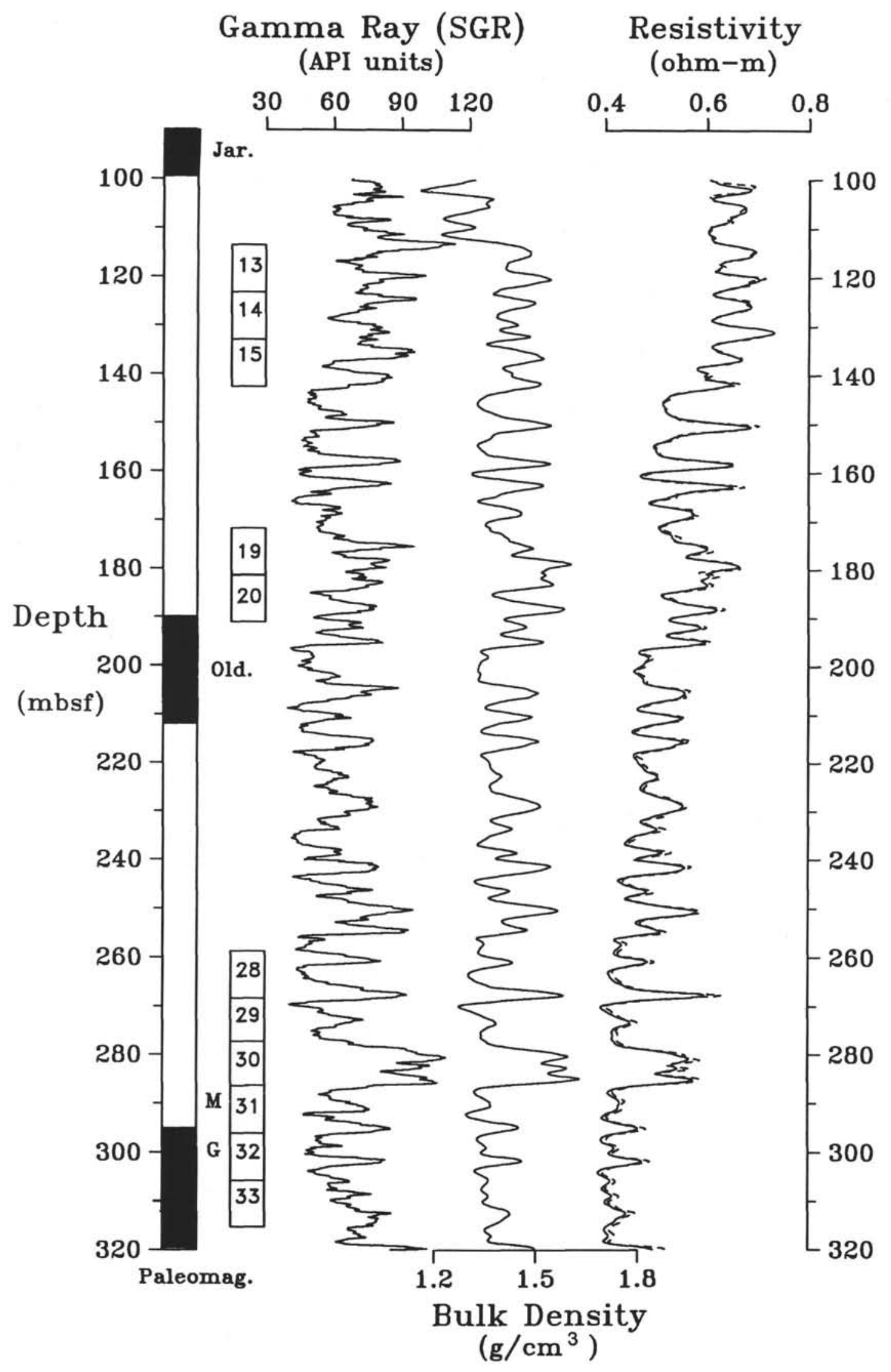

Figure 7. Selected logging data from Hole 798B. Also shown are the paleomagnetic reversal boundaries and the positions of the three core intervals selected for channel sampling (Cores 128-798B-13H to $-15 \mathrm{H}, 19 \mathrm{X}-20 \mathrm{X}$, and $28 \mathrm{X}-33 \mathrm{X}$ ). 


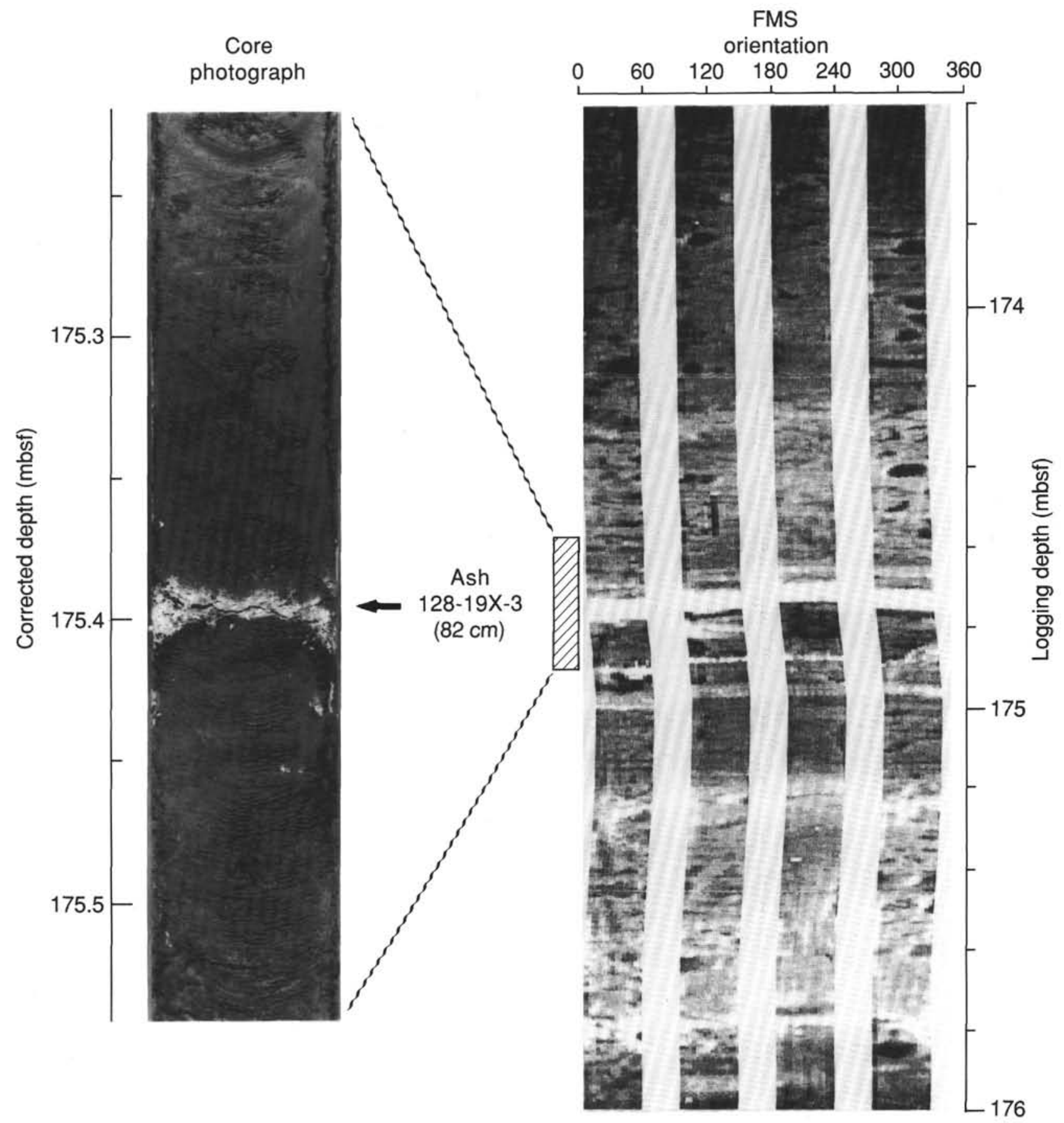

Figure 8. Example of core-log correlations using volcanic ashes. Core photograph is of ash layer in Core 128-798B-19X-3 (82 cm) at $175.40 \mathrm{mbsf}(\mathrm{depths}$ corrected for core expansion). The formation microscanner (FMS) microresistivity images of this interval are shown at right. The images are azimuthal $\left(0^{\circ}-360^{\circ}\right.$ magnetic declination, left-to-right) traces of four orthogonal pads which are pressed against the borehole wall. The ash layer appears as a bright (highly resistive) band at a $174.70 \mathrm{mbsf}$ logging depth.

and logs have been removed. We refer to these new, adjusted core depths in subsequent discussions of core and log data comparisons.

Variations in opal content dominate the sediment physical properties. Correlations between opal percent and the core physical properties data are shown in Figure 11 (data are from Ingle, Suyehiro, von Breymann, et al., 1990). The correlations are based on samples from all three sampled intervals (Cores 128-798B-13 to $-15 \mathrm{H}, 19-20 \mathrm{X}$, and $28-33 \mathrm{X}$ ). These data demonstrate that increases in opal content result in lower dry bulk densities and grain densities and higher porosity values. No significant correla- tions were observed between $\mathrm{CaCO}_{3} \%$ and the physical property data. Carbonate values average $6.5 \%$ within Cores $13 \mathrm{H}-15 \mathrm{H}$, and shipboard analyses indicate that $\mathrm{CaCO}_{3}$ decreases to $\sim 1 \%$ below Core $15 \mathrm{H}(\sim 150 \mathrm{mbsf})$.

\section{Terrigenous Mineralogy}

The sediments average between $70 \%$ and $90 \%$ terrigenous material. We conducted quantitative X-ray diffraction (XRD) on bulk samples to evaluate the mineralogy of this material and quartz (average $=12 \%$ ), 
Table 2. Ash layer correlations of drilling and logging depths.

\begin{tabular}{lccc}
\hline Ash layer & $\begin{array}{c}\text { Drilling depth" } \\
\text { (mbsf) }\end{array}$ & $\begin{array}{c}\text { Logging depth } \\
\text { (mbsf) }\end{array}$ & $\begin{array}{c}\text { Offset } \\
(\mathrm{m})\end{array}$ \\
\hline $128-798 \mathrm{~B}-15 \mathrm{H}-7(55 \mathrm{~cm})$ & 140.70 & 140.40 & +0.30 \\
$128-798 \mathrm{~B}-19 \mathrm{X}-3(82 \mathrm{~cm})$ & 175.40 & 174.70 & +0.70 \\
$128-798 \mathrm{~B}-30 \mathrm{X}-4(40-45 \mathrm{~cm})$ & 282.00 & 280.50 & +1.50 \\
\hline
\end{tabular}

"ODP core depths have been adjusted to equal $100 \%$ of the cored interval to account for post-recovery core disturbance due to gas expansion.

feldspar (7\%), muscovite (10\%), and chlorite (2\%) were found to be the dominant components. While these are quantitative estimates they are probably not accurate weight percent values: XRD calcite estimates were very linear with coulometer estimates, but were too low by a factor of 1.55 . Quartz was particularly abundant, with estimated abundances ranging between $6 \%$ and $18 \%$ by weight. Shipboard smear slide observations indicated that quartz was the dominant silt-sized terrigenous component. Hole $798 \mathrm{~B}$ is located on a ridge that rises above the surrounding bathymetry so the abundance of silt-sized quartz is tentatively interpreted to reflect an eolian component emanating from upwind sources in Asia, most likely the Chinese loess deposits (e.g., Fig. 1). Typical loess is composed of 50\%-
$70 \%$ quartz, $5 \%-30 \%$ feldspar, $5 \%-10 \%$ mica, with minor abundances of carbonate, and clay minerals (Pye, 1987, p. 229). Illite, montmorillonite, and chlorite are the dominant minerals within the clay fraction of the Luochuan and Longxi loess sections in China (Zheng Hong-han, 1984), and these same minerals are common in the clay fraction of the Sea of Japan sediments (P. Debrabant, unpubl. data). The correlation between terrigenous percent and quartz $\left(r^{2}=0.53\right.$; Fig. 12) suggests that the terrigenous component may be reflecting variations in eolian supply; however, flux data will be needed to fully consider this question.

\section{Discussion}

The results shown in Figures 10 and 11 demonstrate that the log responses are primarily reflecting changes in sediment properties associated with variations in biogenic opal and terrigenous sedimentation. In the absence of an oxygen isotopic time-scale we do not have sufficient time control to determine whether the variations are due to changes in opal supply (surface productivity) or changes in terrigenous (eolian dust) supply. However, the core-log comparisons demonstrate that the logs are reflecting real sediment compositional changes and these results prompt an important question: Can the log responses be used to predict the observed core data?

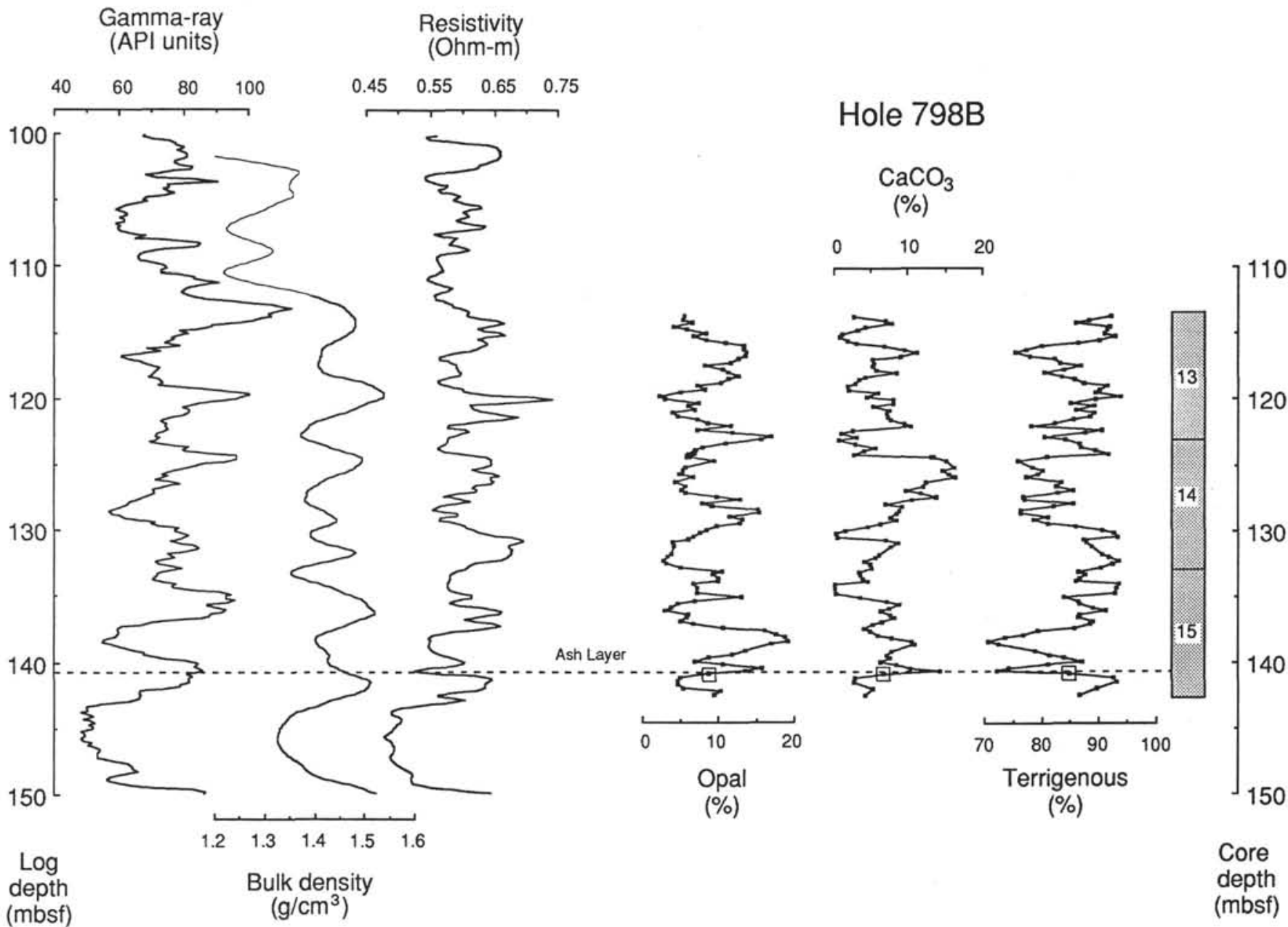

Figure 9. Comparison of logging and core data for the interval represented by Cores 128-798B-13H, -14H, and - 15H. A volcanic ash layer in Core 128-798B-15H-7 $(55 \mathrm{~cm})$ was recognized in formation microscanner (FMS) images and core photographs, and drilling depths were depth-shifted to correlative logging depths (Table 2). Note the correspondence between the spherically-focused resistivity $\log$ (SFL) and the opal percent data. 


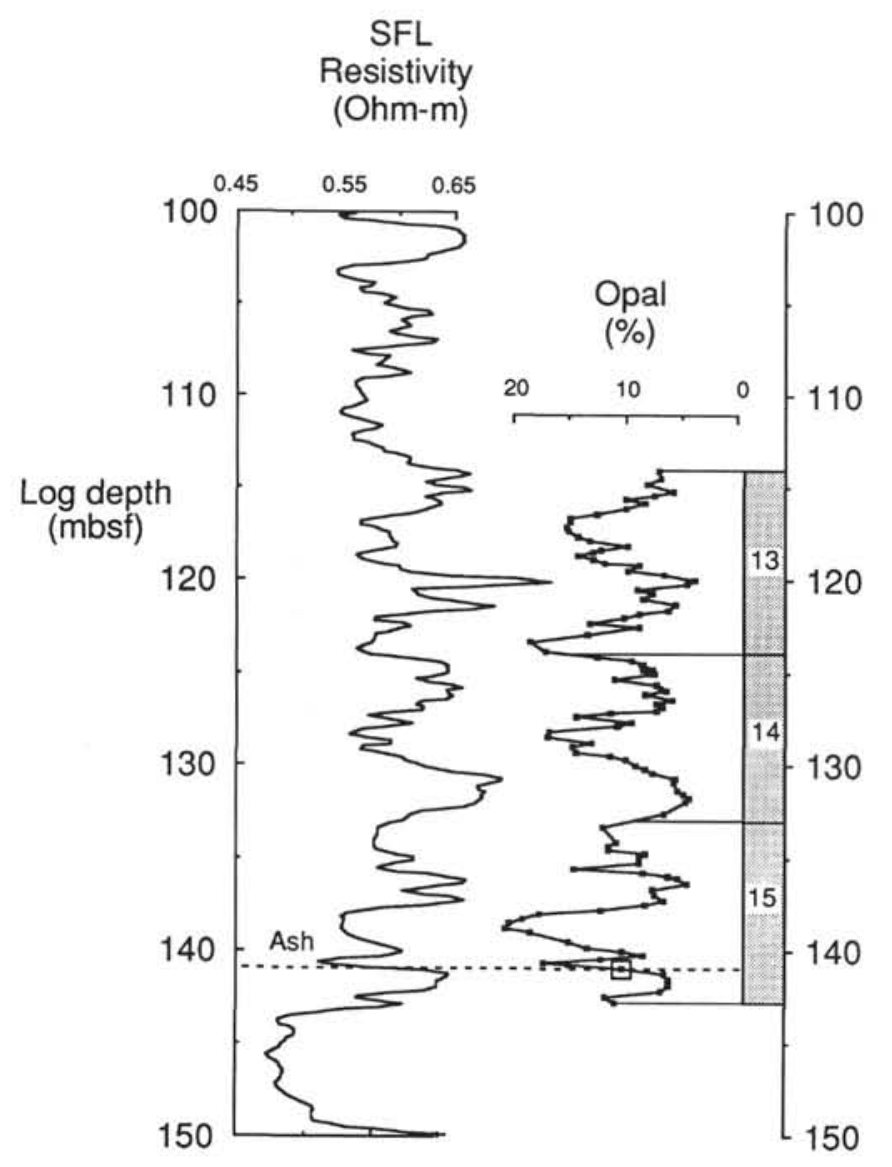

Figure 10. Correlation of the spherically focused resistivity (SFL) $\log$ with the opal percent core data. The core data were correlated to the SFL log using an inverse correlation program (CORPAC; Martinson et al., 1982). The squaredcorrelation between the log and core data is 0.84 .

\section{Log-based Estimates of Sediment Composition}

The simplest model relating the log responses to lithological variations is to assume that the various acoustic, electrical, and nuclear log measurements have direct, linear responses to variations in sediment composition. While this is probably a viable first-order assumption, it is clearly an inadequate model. Porosity, for example, is proportional to the inverse square-root of resistivity (e.g. Archie, 1942). However, we proceed with the assumption of linearity to estimate the amount of core information embedded within the log data. This was accomplished with a stepwise multiple linear regression analysis using all of the logging data as input variables to predict the individual opal, $\mathrm{CaCO}_{3}$, and terrigenous percentage records for the Core $128-798 \mathrm{~B}-13 \mathrm{H}$ to $-15 \mathrm{H}$ depth interval. A standard F-test selects which log responses are used in the final regression equation. Eleven logs were used as input variables (Schlumberger abbreviations in parentheses): Spectral gamma ray (SGR), $\mathrm{K} \%$, Th\%, U\%, bulk density (RHOB), spherically-focused- (SFL), medium- (ILM), and deep-induction (ILD) resistivity, sonic slowness (DTLN), neutron porosity (NPHI), and $\mathrm{Al} \%$ from the aluminum clay tool.

The predicted opal, $\mathrm{CaCO}_{3}$, and terrigenous percent data are shown adjacent to the actual composition data from Cores 128-798B$13 \mathrm{H}$ to $-15 \mathrm{H}$ in Figure 13 . The opal and terrigenous predictions were very good $\left(r^{2}=0.84\right.$ and 0.59 , respectively), whereas the $\mathrm{CaCO}_{3}$ prediction was poor $\left(\mathrm{r}^{2}=0.20\right)$. The SFL, K\%, Th\%, and DTLN logs were used in the opal prediction equation, listed in decreasing order of their importance to the regression equation. The importance of the SFL log to the opal prediction reflects the strong interrelationships
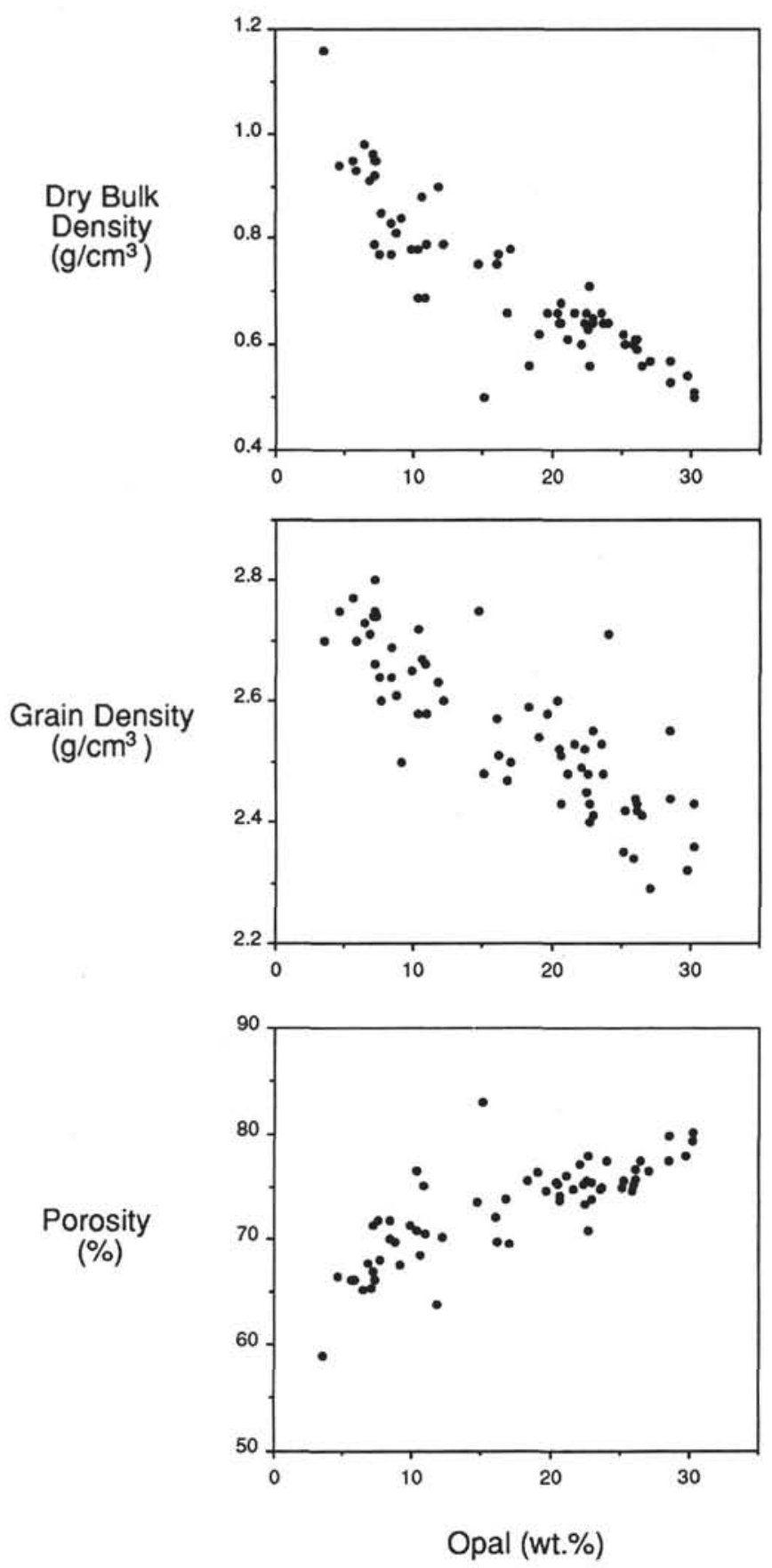

Figure 11. Effect of changes in biogenic (mainly diatomaceous) opal concentration on sediment physical properties: dry-bulk density, grain density, and porosity.

between opal content, sediment porosity, and electrical resistivity. The SGR, $\mathrm{Al} \%$, SFL, and ILM logs were used in the $\mathrm{CaCO}_{3}$ prediction equation. The SFL, SGR, DTN, Al\%, and $\mathrm{K} \%$ logs were used in the terrigenous prediction equation. The SGR log monitors the total natural radioactive decay contributions from $\mathrm{K}, \mathrm{Th}$, and $\mathrm{U}$, and its importance in the terrigenous prediction equation reflects the association of these elements within the terrigenous mineralogy.

These results demonstrate that a significant proportion of the sediment composition variance can be extracted from the log data using a simple linear model. Efforts are currently underway to quantitatively model the various $\log$ responses expected from the known 


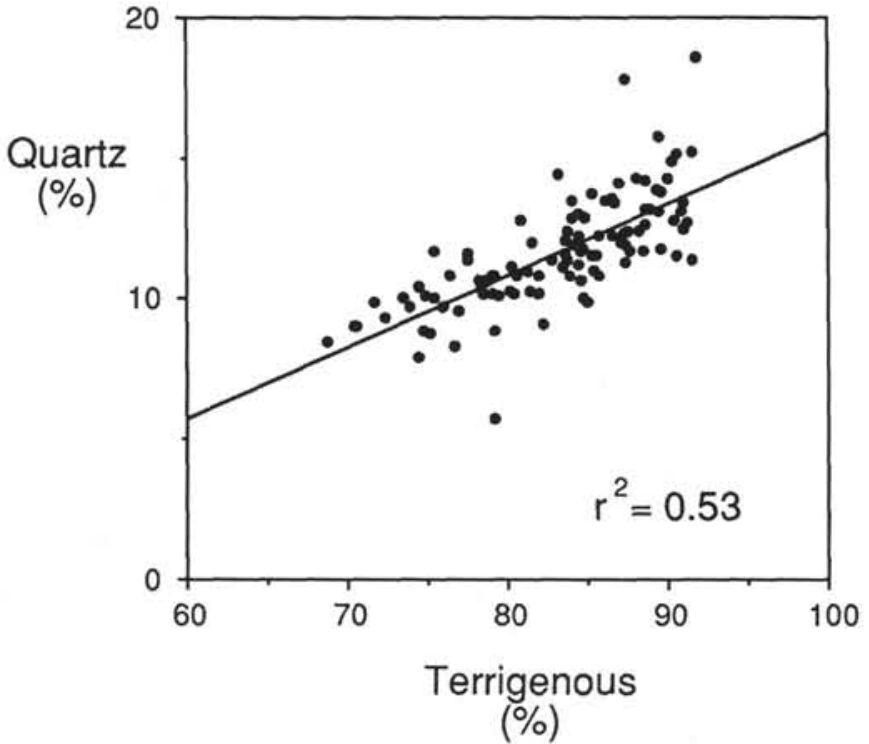

Figure 12. Correlation between terrigenous sediment (calculated as $100-$ opal-carbonate) and quartz abundance estimated by quantitative $\mathrm{X}$-ray diffraction. Smear-slide observation indicates that silt-sized quartz is a dominant component of the terrigenous mineralogy. Feldspar, muscovite, and chlorite were also present in lower abundances.

sediment compositional data using proprietary Schlumberger algorithms. Ultimately, we intend to incorporate the core data from Cores 128-798B-19X to $-20 \mathrm{X}$ and $128-798 \mathrm{~B}-28 \mathrm{X}$ to $-33 \mathrm{X}$ into generalized equations suitable for the entire logged interval.

\section{Pliocene-Pleistocene Climate Change in the Sea of Japan}

The log data shown in Figure 7 demonstrate that opal and terrigenous sedimentation has varied rhythmically over the entire 1.0-2.8 Ma interval. The 5- to 6-m cyclicity within the logs (Fig. 7) is equivalent to a periodicity of $\sim 40 \mathrm{k} . \mathrm{y}$. based on the average sedimentation rate $(\sim 13 \mathrm{~cm} /$ k.y.) over this interval. The log data have several features in common with the Pliocene-Pleistocene marine $\delta^{18} \mathrm{O}$ record from ODP Site 607 (Raymo et al., 1989) and the two records are compared in Figure 14. The gamma-ray log (SGR) was converted to a time-series using the Hole $798 \mathrm{~B}$ paleomagnetic reversal boundaries. Using the CORPAC signal correlation program (Martinson et al., 1982), minor adjustments were made in the SGR time-series within the uncertainties of the paleomagnetic control points to improve its alignment with the $\delta^{18} \mathrm{O}$ record. While this greatly improved the alignment of the two records (Fig. 14), no sharp discontinuities were introduced into the age-depth plot (Fig. 15).

The similarity between the SGR and $\delta^{18}$ Orecords is striking. The SGR and $\delta^{18} \mathrm{O}$ records are both dominated by variance at the $41-\mathrm{k} . \mathrm{y}$. orbital obliquity component; high SGR values are coincident with high (glacial) $\delta^{18} \mathrm{O}$ values. The SGR power spectra for the paleomagnetic time scale and the $\delta^{18} \mathrm{O}$ "tuned" time-scale are shown in Figure 16. The result of the fine-scale alignment with the $\delta^{18} \mathrm{O}$ record was to considerably sharpen the power at the 41 k.y. periodicity. The SGR data were resampled at constant a $t(1$ k.y.), detrended, and power spectra were estimated with the Blackman-Tukey method of spectral analysis using one-third lags and no prewhitening. Despite detrending the data, there is considerable power at very long periodicities (100 k.y.; Fig. 16) so the contribution of variance at the $41 \mathrm{k} . \mathrm{y}$. band is only $20 \%$ of the total. This increases to over $40 \%$ if this low-frequency component is excluded.

The triple-peak maximum above the Matuyama/Gauss reversal (isotopic stages 100 to $96 ; 2.4-2.3 \mathrm{Ma}$ ) characteristic in most detailed $\delta^{18} \mathrm{O}$ records is also apparent in the SGR record. The rapid rise in $\delta^{18} \mathrm{O}$ values has been interpreted to reflect the rapid but short-lived expansion of Northern Hemisphere ice sheets, as evidenced by the first abundant appearance of ice-rafted debris in the North Atlantic (Backman, 1979; Shackleton et al., 1984; Raymo et al., 1986; Jansen and Sjoholm, 1991). The maximum SGR values indicate that terrigenous deposition in the Sea of Japan is high during this interval.

Because we do not have component flux data, we interpret the log variations to reflect variations in eolian terrigenous and/or biogenic opal supply. Although the opal percent data vary by a factor of five and the terrigenous percent data only vary by a factor of two (at most) the bulk density values are highest within terrigenous-rich intervals (Figs. 7 and 11), so it is difficult to suggest which component dominates. Most probably, the logs reflect a balance between the supply of terrigenous and biogenic sediment associated with glacialinterglacial climate change.

\section{Variations in Terrigenous Sediment Supply}

The peaks in the $\log$ responses may reflect increased Asian eolian dust supply associated with glacial maxima. An eolian terrigenous linkage is suggested by the mineralogical affinity of the Hole 798B terrigenous sediments and the Chinese loess, the well-documented pattern of glacial aridity in central China, and the correspondence of the SGR, resistivity, and bulk density logs with ice volume (Fig. 14). We estimated the peak ("glacial") terrigenous flux at Hole 798B to be $\sim 12 \mathrm{~g} / \mathrm{cm}^{2} / \mathrm{k}$.y. based on available dry-bulk density (Fig. $11 ; \sim 1.0 \mathrm{~g} / \mathrm{cm}^{3}$ ), terrigenous content $(90 \%)$, and average sedimentation rate $(13 \mathrm{~cm} / \mathrm{k} . \mathrm{y}$. data. This estimate is intermediate between higher values upwind $\left(\sim 38 \mathrm{~g} / \mathrm{cm}^{2} / \mathrm{k}\right.$.y. for loess at Luochuan, China; calculations based on data provided by G. Kukla) and lower values downwind $\left(\sim 0.6 \mathrm{~g} / \mathrm{cm}^{2} / \mathrm{k}\right.$.y. eolian accumulation rates at Core V21-146, 3200 km downwind; Hovan et al., 1989).

The relatively low and constant SGR values within the Olduvai subchron at $\sim 1.75$ Ma suggest a reduced supply of eolian detritus during this interval. This observation is consistent with paleobotanical and sedimentological evidence for a prolonged warm and relatively humid climate in central China during this interval. A series of dense polygenetic soils (termed WS3; Kukla, 1987) are found within the Chinese loess-soil sequences within a normal polarity unit corresponding to the Olduvai subchron. Pollen analyses indicate abundant broadleaf (birch and oak) tree pollen, that suggest an open woodland terrain. Similarly, a prolonged interval of unusually low amplitude radiolarian assemblage variations persists in the northwest Pacific between 1.6 and $1.82 \mathrm{Ma}$, implying minimal variations in surface water properties (Morley and Dworetzky, in press).

There is a consistent pattern of loess deposition during glacial maxima and the formation of soil horizons during interglacial periods for the last $\sim 1 \mathrm{Ma}$. The loess record bears a striking resemblance to the marine $\delta^{18} \mathrm{O}$ ice volume record (Heller and Liu, 1984; Kukla et al., in press). The first occurrence of loess is just above the Matuyama/Gauss reversal at $\sim 2.4 \mathrm{Ma}$, roughly coincident with the growth of Northern hemisphere ice sheets. Infrequent pollen within the loess is dominated by grasses and sedge, suggesting a much more continental climate (colder and drier) than the broadleaf tree pollen within the soils (warm and humid) (Liu et al., 1985). The silty, quartz-rich particles within the loess are considered to originate from dry-season deflation of glacial outwash stream sediments. These particles are transported by strong winds associated with the expanded ice cover, and the resulting dust fallout is widespread and copious. Loess thickness decreases with increasing distance from dust sources in the continental interior (Liu et al., 1985). A 400-k.y. record of eolian dust accumulation in Core V21-146 from the adjacent western Pacific (Fig. 1) closely parallels the Chinese loess record, suggesting that the continental aridity signal is preserved downwind in marine sediments (Hovan et al., 1989). Considering that the modern supply of Asian dust to the northwest Pacific is among the highest eolian sources in the world (Uematsu et al., 1983), the dust fluxes to the Sea of Japan associated with the deposition of loess in China must have been considerably enhanced during glacial maxima. 
Opal

(\%)

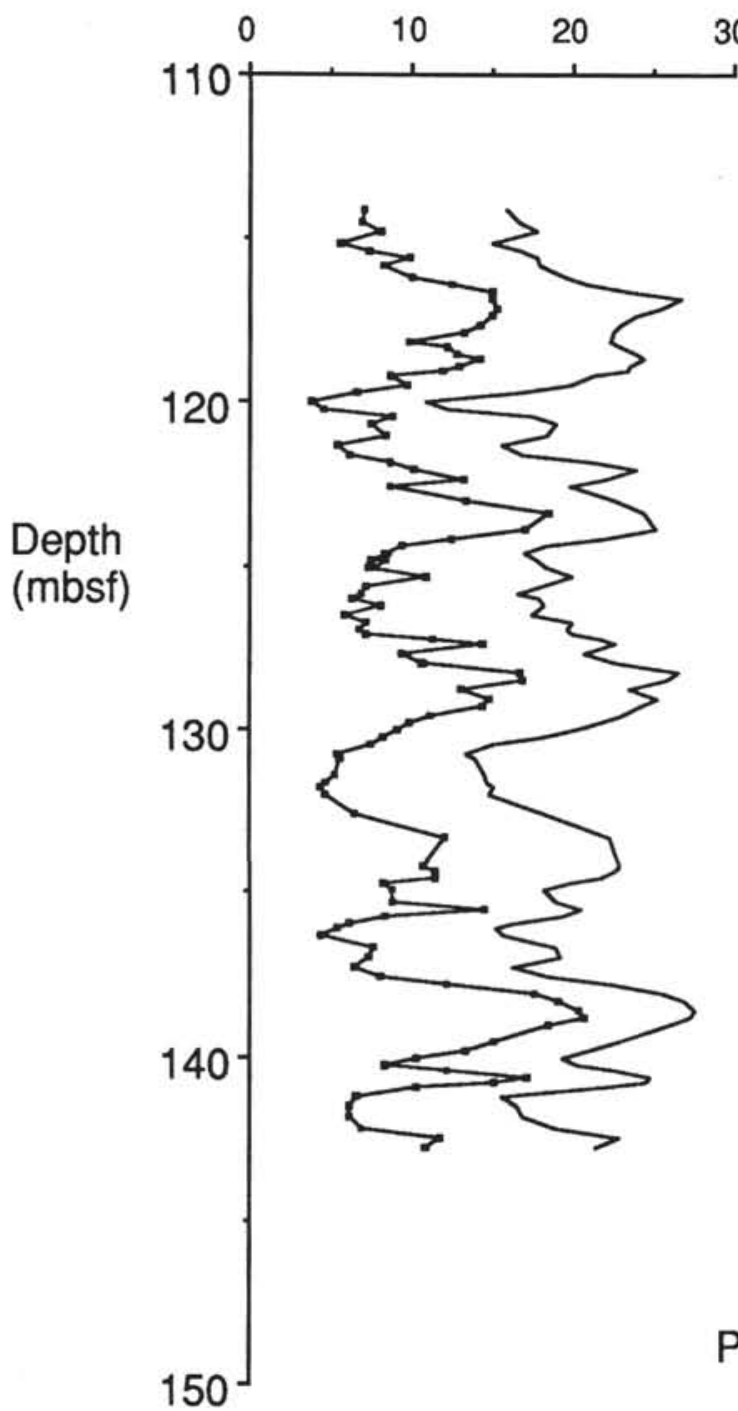

Carbonate

(\%)

$0 \quad 10 \quad 20$
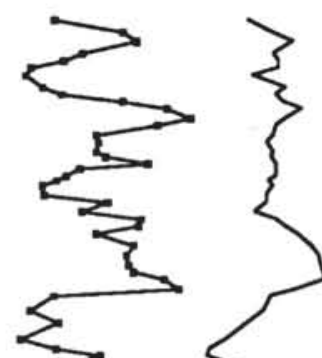

3
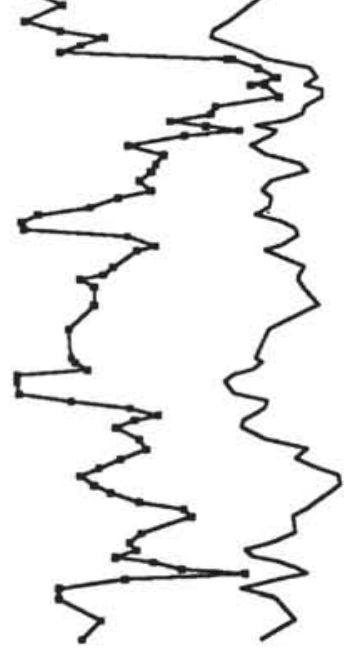

Actual core data (-)

Predicted from logs (-)
Terrigenous

(\%)
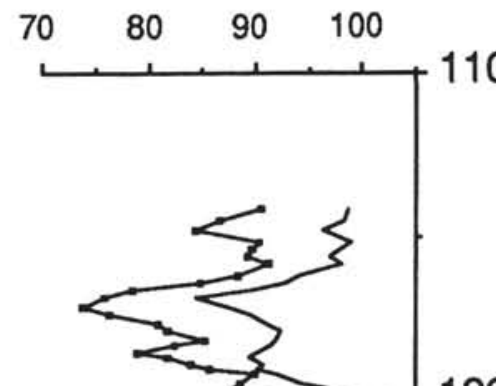

$-120$

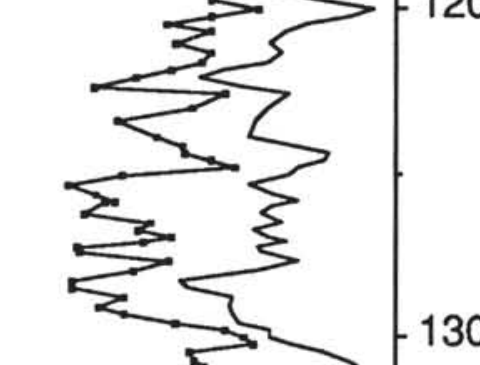

Figure 13. Comparison of measured opal, carbonate, and terrigenous percent core data (symbols) with log-based predictions of the same components from a multiple linear regression procedure (no symbols). The log-based predictions have been shifted by $+10 \%$ to offset the two curves. The opal and terrigenous percent predictions were good $\left(r^{2}=0.84\right.$ and 0.59 , respectively), whereas the carbonate prediction was poor $\left(r^{2}=0.20\right)$.

\section{Variations in Biogenic Opal Supply}

The opal-resistivity correlation in Figure 10 suggests that the troughs in the log responses (low SGR, resistivity, bulk density) could also reflect increased biogenic opal supply associated with interglacial intervals. Very low radiolarian abundances in glacial levels of Core RC12-379 in the Sea of Japan near the Oki Ridge suggest that glacial intervals are characterized by reduced surface productivity (Morley et al., 1986). Results from other studies (Oba, 1983; Matoba, 1984) have demonstrated that glacial sediments are commonly laminated, suggesting that deep convection within the Sea of Japan was severely reduced due to sea ice expansion in the northern reaches of the basin. The highly efficient nutrient regeneration within the modern basin is attributable to intense internal deep convection and its attendant upwelling of nutrient-rich waters (Matoba, 1984). In contrast, the glacial Sea of Japan is depicted as a poorly ventilated basin with low surface productivity (Miyake et al., 1968; Ujiie and
Ichikura, 1973). Glacioeustatic sea-level variations or climaticallymodulated variations in sea ice extent are the primary candidates for glacial-interglacial variations in surface productivity, and hence opal content, in the Sea of Japan.

\section{SUMMARY}

Downhole logging can be a highly efficient means for acquiring basic paleoclimate data, but intrinsic limitations of the method such as tool resolution and $\log$ responses to known lithological variations need to be addressed. We consider these issues using logging data collected at Hole 798B on the Oki Ridge in the Sea of Japan. This site is ideal for this study because of the ridge location, high sedimentation rates (12-14 cm/k.y.), and geographic position in a climatically-sensitive region.

1. The vertical resolution of a given logging device sets an upper limit on its temporal resolution. Using a simple numerical model 


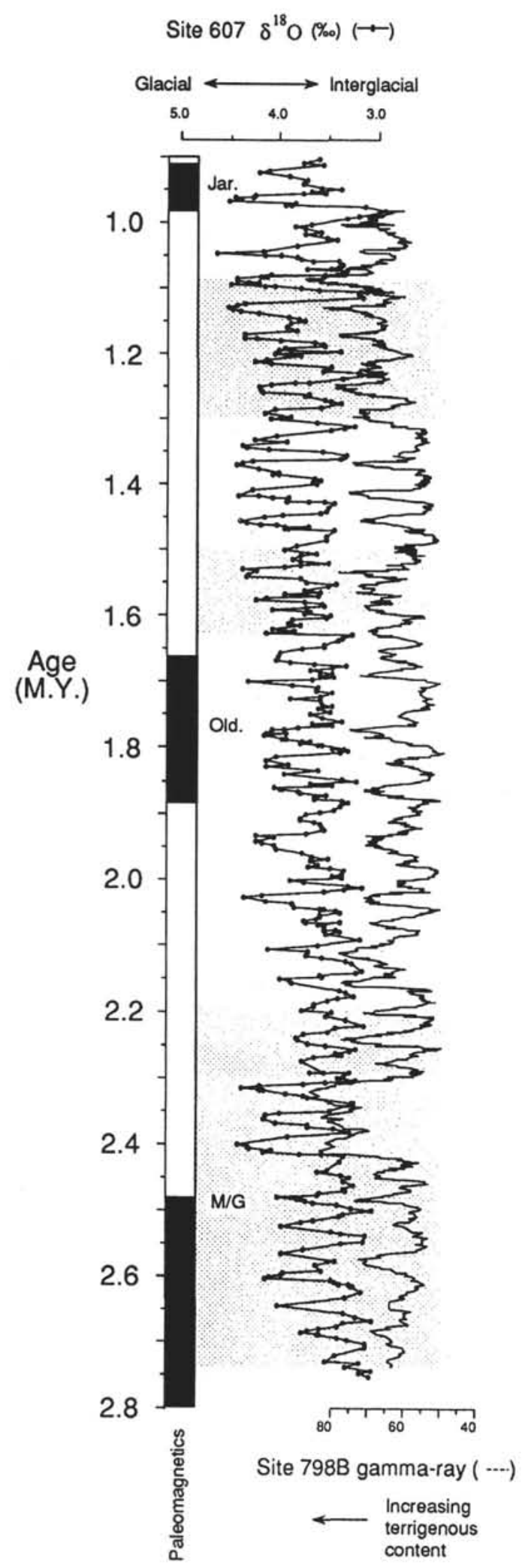

Figure 14. Correlation of the Hole 798B SGR gamma-ray log with the marine $\delta^{18}$ O record from Site 607 in the North Atlantic (Raymo et al., 1989; Ruddiman et al., 1989). The SGR time series was initially constrained using the paleomagnetic reversal boundaries. Minor adjustments to the SGR time series were performed using the CORPAC correlation program to improve its alignment with the Site $607 \delta^{18} \mathrm{O}$ record. The age-depth plot resulting from this process is shown in Figure 15. designed to simulate tool response to a periodically-varying lithology, we calculated estimates for the minimum required sedimentation rates needed for the logging tools to resolve bedding cycles occurring at the 100 k.y., 41 k.y., and 23-19 k.y. orbital periodicities (Table 1).

2. To investigate the sedimentologic origin of the 5- to 6-m bedding cycles apparent within the Hole 798B log data, contiguous $30-\mathrm{cm}$ channel samples were taken from Cores 128-798B-13H, -14H, and $-15 \mathrm{H}$ to mimic tool resolution. These samples were analyzed for biogenic opal, carbonate, terrigenous percent, and bulk mineralogy by X-ray diffraction. Core-log correlations were established using ash layers identified in core photographs and formation microscanner (FMS) microresistivity log images.

3. Core-log comparisons demonstrate that the log cycles are primarily reflecting variation in diatomaceous opal and terrigenous sediment supply. The low-amplitude carbonate percentages were not clearly represented in the log data. The acoustic, electric, and nuclear logs were used to estimate opal, carbonate, and terrigenous percent data using a multiple linear regression technique. The log-based opal and terrigenous predictions were good $\left(r^{2}=0.84\right.$ and 0.59 , respectively), whereas the carbonate prediction was poor $\left(r^{2}=0.20\right)$.

4. The 5- to 6-m log cycles correspond to $\sim 40 \mathrm{k} . \mathrm{y}$. based on a paleomagnetic reversal stratigraphy for the 1.0-2.8 Ma logged interval. There is a close correspondence of the log data with the PliocenePleistocene marine $\delta^{18} \mathrm{O}$ record. Quartz is highly correlated with terrigenous fraction variations and the bulk mineralogical assemblage is similar to that of Chinese loess, a probable upwind source of eolian dust. The Chinese loess deposits demonstrate a linkage between glacial climate and Asian aridity, so the log variations may be reflecting periodic increases in terrigenous concentration due to the downwind propagation of this signal. In the absence of flux data we cannot exclude the possibility that the logs are also reflecting variations in biogenic opal supply.

\section{ACKNOWLEDGMENTS}

This research was supported by a JOI/USSAC grant to P. deMenocal and J. Bristow. We thank Pat Malone for conducting the sediment analyses. Manuscript reviews and helpful criticisms were provided by W. Ruddiman, J. King, J. Morley, and B. Phinney. This is LamontDoherty Geological Observatory publication number 4931.

\section{REFERENCES}

Allen, D., Barber, T., Flaum, C., Hemingway, J., Anderson, B., des Ligneris, S., Everett, B., and Morriss, C., 1988. Advances in high-resolution logging. Tech. Rev., 36:4-15.

Archie, G. E., 1942. The electrical resistivity log as an aid in determining some reservoir characteristics. J. Pet. Tech., 5:1-8.

Backman, J., 1979. Pliocene biostratigraphy of DSDP Sites 111 and 116 from the North Atlantic Ocean and the age of the Northern Hemisphere Glaciation. Stockholm Contrib. Geol., 32:115-137.

Blanc, M., Leinen, M., and Prospero, J., 1985. Major Asian aeolian influx indicated by the mineralogy of aerosols and sediments in the western North Pacific. Nature, 314:84-86.

Braaten, D. A., and Cahil, T. A., 1986. Size and composition of Asian dust transported to Hawaii. Atmos. Emv., 20:1105-1110.

Fairbanks, R. G., 1989. A 17,000-year glacio-eustatic sea level record: influence of glacial melting rates on the Younger Dryas event and deep-ocean circulation. Nature, 342:637-642.

Hamano, Y., Krumsiek, L., Vigliotti, K., and Wippern, J., in press. PliocenePleistocene magnetostratigraphy of sediment cores from the Japan Sea. In Tamaki, K., Suyehiro, K., Allan, J., McWilliams, M., et al., Proc. ODP, Init. Repts., 127/128, Pt. 2: College Station, TX (Ocean Drilling Program).

Hays, J. D., Imbrie, J., and Shackleton, N. J., 1976. Variations in the Earth's orbit: pacemaker of the ice ages. Science, 194:1121-1132.

Heller, F., and Liu, T. S., 1984. Magnetism of chinese loess deposits. Geophys. J. R. Astron. Soc., 77:125-141.

Heusser, L., and Morley, J., 1990. Climatic change at the end of the last glaciation in Japan inferred from pollen in three cores from the northwest Pacific Ocean. Quat. Res., 34:101-110. 
Hovan, S. A., Rea, D. K., Pisias, N. G., and Shackleton, N. J., 1989. A direct link between the china loess and marine $\delta^{18} \mathrm{O}$ records: aeolian flux to the North Pacific. Nature, 340:296-298.

Imbrie, J., Hays, J. D., Martinson, D. G., McIntyre, A., Mix, A. C., Morley, J. J., Pisias, N. G., Prell, W. L., and Shackleton, N. J., 1984. The orbital theory of Pleistocene climate: support from a revised chronology of the marine delta $\delta^{18} \mathrm{O}$ record. In Berger, A., Imbrie, J., Hays, J., Kukla, G., and Saltzman, B. (Eds.), Milankovitch and Climate (Pt. 1): Dordrecht (D. Reidel), 269-305.

Ingle, J. C., Jr., 1975. Pleistocene and Pliocene foraminifera from the Sea of Japan. In Karig, D. E., Ingle, J. C., Jr., et al., Init. Repts. DSDP, 31: Washington (U.S. Govt. Printing Office), 693-702.

Ingle, J. C., Jr., Suyehiro, K., von Breymann, M. T., et al., 1990. Proc. ODP, Init. Repts., 128: College Station, TX (Ocean Drilling Program).

Jansen, E., and Sj-holm, J., 1991. Reconstruction of glaciation over the past 6 Myr from ice-borne deposits in the Norwegian Sea. Nature, 349:600-603.

Kasuya, M., 1990. Fission-track ages of tuff layers related to the PliocenePleistocene boundary on the Boso peninsula, Japan. Quat. Res., 33:86-93.

Kobayashi, K., and Nomura, M., 1972. Iron sulfides in the sediment cores from the Sea of Japan and their geophysical implications. Earth Planet. Sci. Lett., 16:200-206.

Kukla, G., 1987. Loess stratigraphy in central China. Quat. Sci. Rev., 6:191-219.

Kukla, G., An, Z. S., Melice, J. L., Gavin, J., and Xiao, J. L., in press. Magnetic susceptibility of chinese loess. Trans. R. Soc. Edinburgh.

Kukla, G., Heller, F., Liu, X. M., Xu, T. C., Liu, T. S., and An, Z. S., 1988. Pleistocene climates in China dated by magnetic susceptibility. Geology, 16:811-814.

Leinen, M., 1989. The Late Quaternary record of atmospheric transport to the northwest Pacific from Asia. In Leinen, M., and Sarnthein, M. (Eds.), Paleoclimatology and Paleometeorology: Modern and Past Patterns of Glocal Atmospheric Transport. New York: (Kluwer Acad. Publ.), 693-732.

Liu, T. S., 1985. Loess and the Environment: Beijing (China Ocean Press).

Liu, T., Gu, X., An, Z., and Fan, Y., 1981. The dustfall in Beijing, China, on April 18, 1980. Spec. Pap.-Geol. Soc. Am., 186:149-158.

Martinson, D. G., Menke, W., and Stoffa, P., 1983. An inverse approach to signal correlation. J. Geophys. Res., 87:4807-4808.

Matoba, Y., 1984. Paleoenvironment of the Sea of Japan. In Oertli, H. J. (Ed.), Benthos '83 2nd Intern. Symp. Benthic Foraminifera: 409-414.

Miyake, Y., Sugimura, Y., and Matsumoto, E., 1968. Ionium-thorium chronology of Japan Sea cores. Rec. Oceanogr. Works Jpn., 9:189-195.

Morley, J., and Dworetzky, B., in press. Evolving Pliocene-Pleistocene climate: a North Pacific perspective. Quat. Sci. Rev.

Morley, J., Heusser, L., and Sarro, T., 1986. Latest Pleistocene and Holocene paleoenvironment of Japan and its marginal sea. Palaeogeogr., Palaeoclimatol., Palaeoecol., 53:349-358.
Mortlock, R. A., and Froelich, P. N., 1989. A simple method for the rapid determination of biogenic opal in pelagic marine sediments. Deep-Sea Res. Part A, 36:1415-1426.

Oba, T., 1983. Oxygen isotope analysis. Ocean Res. Inst., Univ. of Tokyo.

Pye, K., 1978. Aeolian Dust and Dust Deposits: New York (Academic Press), 97-98.

Raymo, M. E., Ruddiman, W. F., Backman, J., Clement, B. M., and Martinson, D. G., 1989. Late Pliocene variation in Northern Hemisphere ice sheets and North Atlantic deep water circulation. Paleoceanography, 4:413-446.

Raymo, M. E., Ruddiman, W. F., and Clement, B. M., 1987. Pliocene-Pleistocene paleoceanography of the North Atlantic at DSDP Site 609. In Ruddiman, W. F., Kidd, R. B., Thomas, E., et al., Init. Repts. DSDP, 94 (Pt. 2): Washington (U.S. Govt. Printing Office), 895-901.

Shackleton, N. J., Backman, J., Zimmerman, H., Kent, D. V., Hall, M. A., Roberts, D. G., Schnitker, D., Baldauf, J., Desprairies, A., Homrighausen, R., Huddlestun, P., Keene, J. B., Kaltenback, A. J., Krumsiek, K.A.O., Morton, A. C., Murray, J. W., and Westberg-Smith, J., 1984. Oxygen isotope calibration of the onset of ice-rafting in DSDP Site 552A: history of glaciation in the North Atlantic region. Nature, 307:620-623.

Tamaki, K., 1988. Geological structure of the Sea of Japan and its tectonic implications. Chishitsu Chosasho Geppo, 39:269-365.

Tsukada, M., 1983. Vegetation and climate during the last glacial maximum in Japan. Quat. Res., 19:212-235.

Uematsu, M., Duce, R., Nakaya, S., and Tsunogai, S., 1985. Short-term temporal variability of eolian particles in surface waters of the northwestern North Pacific. J. Geophys. Res., 90:1167-1172.

Uematsu, M., Duce, R., Prospero, J., Chen, L., Merrill, J., and McDonald, R., 1983. Transport of mineral aerosol from Asia over the North Pacific Ocean. J. Geophys. Res., 88:5343-5352.

Ujiié, H., and Ichikawa, M., 1973. Holocene to uppermost Pleistocene planktonic foraminifera in a piston core from the Sanin District, Sea of Japan. Trans. Proc. Paleon. Soc. Japan, 91:137-150.

Verardo, D., Froelich, P. N., McIntrye, A., 1990. Determination of organic carbon and nitrogen in marine sediments using the Carlo Erba NA-1500 Analyzer, Deep-Sea Res. Part A, 37:157-165.

Zheng, H.-H, 1984. Paleoclimatic events recorded in clay minerals in loess of China. In Pecsi, M. (Ed.), Lithology and Stratigraphy of Loess and Paleosols. Geogr. Res. Inst., Hungarian Acad. Sci.

Date of initial receipt: 4 April 1991

Date of acceptance: 5 November 1991

Ms 127/128B-143 
Age (k.y.)

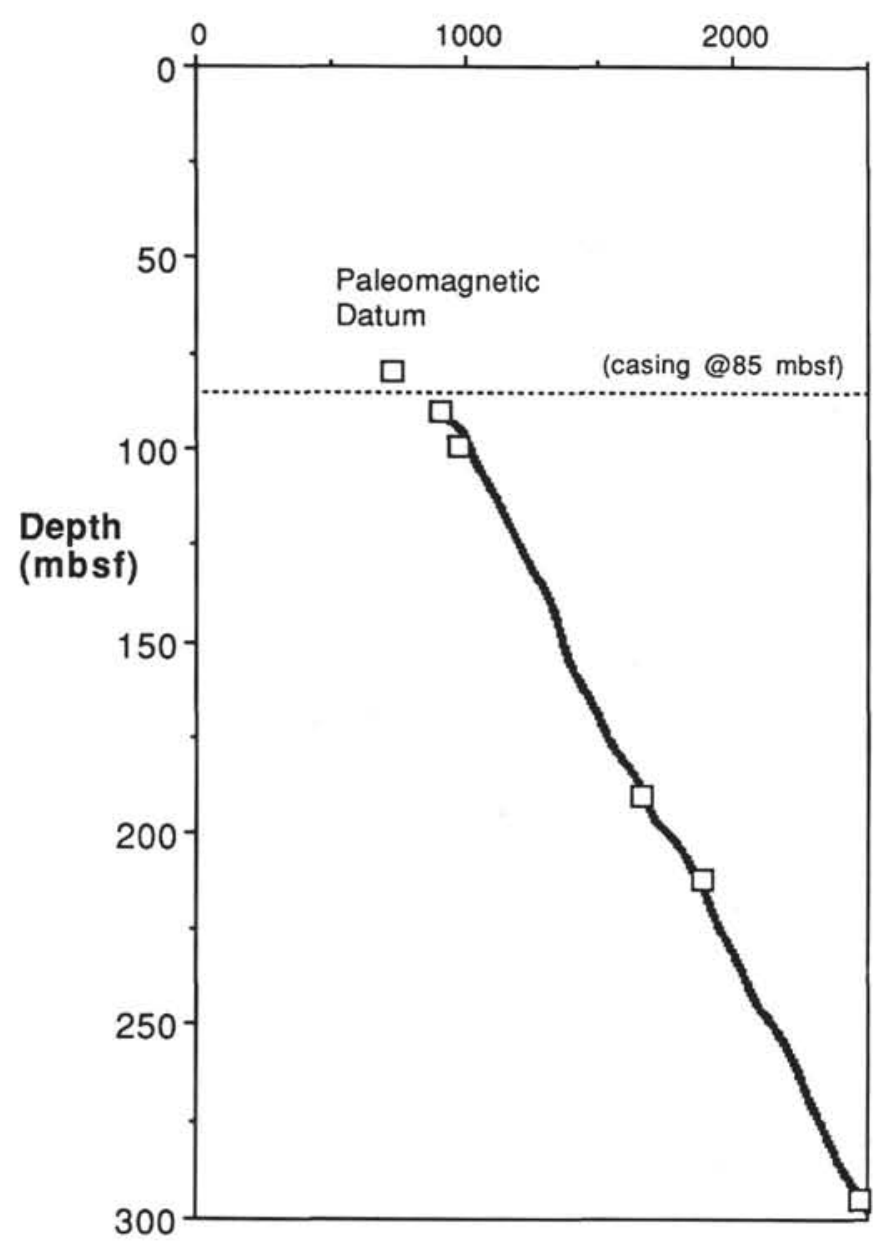

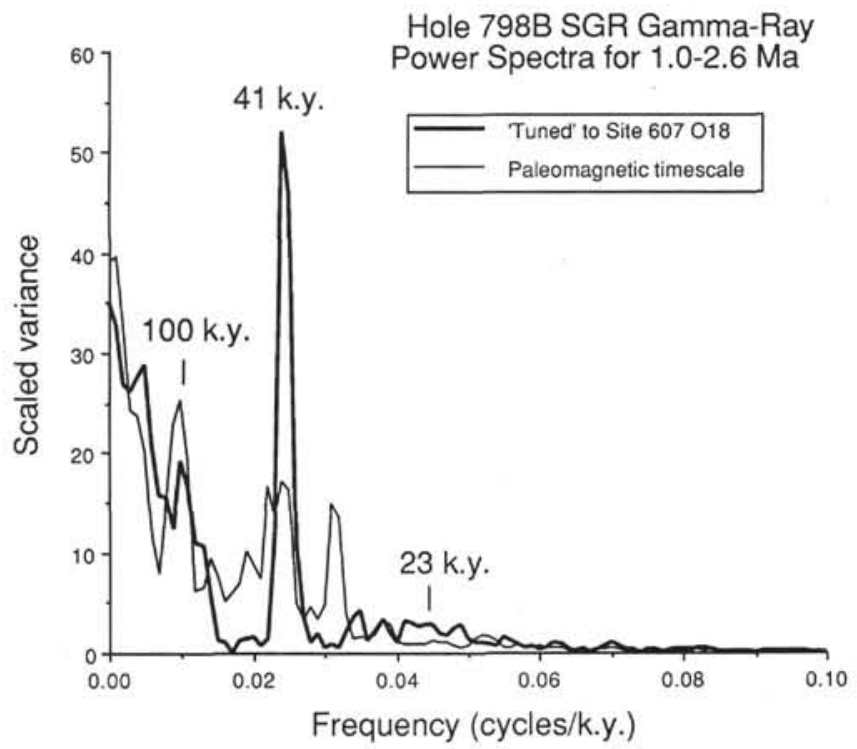

Figure 16. Power spectra of the SGR time series from 1.0 Ma to 2.6 Ma. Data were interpolated to constant $\Delta t$ ( 1 k.y.) and detrended; spectral density is shown as scaled, linear variance. The SGR power spectrum resulting from the correlation of the SGR $\log$ to the Site $607 \delta^{18} \mathrm{O}$ record is shown by the heavier line.

Figure 15. Age-depth relationship for Hole 798B. The open squares denote the positions of the paleomagnetic reversal boundaries, the continuous line represents the mapping function resulting from the correlation of the SGR log to the Site $607 \delta^{18} \mathrm{O}$ record. 